Article

\title{
Eutrophication, Research and Management History of the Shallow Ypacaraí Lake (Paraguay)
}

\author{
Gregorio Alejandro López Moreira M. 1,2,3,4 (D), Luigi Hinegk ${ }^{1}$, Andrea Salvadore ${ }^{1}$, \\ Guido Zolezzi ${ }^{1}$, Franz Hölker ${ }^{2,3}$ (1), Roger Arturo Monte Domecq S. ${ }^{4,5}$, Martina Bocci ${ }^{6}$, \\ Sebastiano Carrer ${ }^{6}$, Luca De Nat ${ }^{6}$, Juan Escribá ${ }^{7}$, Carmen Escribá ${ }^{7}$, Gilberto Antonio Benítez ${ }^{8}$, \\ Claudia Raquel Ávalos ${ }^{8}$, Inocencia Peralta ${ }^{8}$, Mario Insaurralde ${ }^{9}$, Fátima Mereles ${ }^{10}$, \\ Jean Michel Sekatcheff ${ }^{5}$, Andrés Wehrle ${ }^{5}$, Juan Francisco Facetti-Masulli ${ }^{5}$, \\ Juan Francisco Facetti ${ }^{5}$ and Marco Toffolon ${ }^{1, *}$ (iD \\ 1 Department of Civil, Environmental and Mechanical Engineering (DICAM), University of Trento (UniTN), \\ 38123 Trento, Italy; ga.lopez@unitn.it (G.A.L.M.M.); luigi.hinegk@gmail.com (L.H.); \\ andrea.salvadore92@gmail.com (A.S.); guido.zolezzi@unitn.it (G.Z.) \\ 2 Department of Ecohydrology, Leibniz-Institute of Freshwater Ecology and Inland Fisheries (IGB), \\ 12587 Berlin, Germany; hoelker@igb-berlin.de \\ 3 Institute of Biology, Department of Biology, Chemistry and Pharmacy, Freie Universität Berlin (FUB), \\ 14195 Berlin, Germany \\ 4 Centre for Appropriate Technology (CTA), Faculty of Sciences and Technology (FCYT), “Nuestra Señora de \\ la Asunción" Catholic University (UCNSA), 1366 Asunción, Paraguay; roger.monte-domecq@uc.edu.py \\ 5 Faculty of Engineering, National University of Asunción (FIUNA), 2169 San Lorenzo, Paraguay; \\ jmsekatcheff@hotmail.com (J.M.S.); awehrle@ing.una.py (A.W.); jfrafama@rieder.net.py (J.F.F.-M.); \\ jfacetti@ing.una.py (J.F.F.) \\ 6 Thetis S.p.A., 30122 Venice, Italy; martina.bocci.1@gmail.com (M.B.); sebastiano.carrer@thetis.it (S.C.); \\ luca.denat@thetis.it (L.D.N.) \\ 7 INYMA Consult S.R.L., 1580 Asunción, Paraguay; jescribagm@gmail.com (J.E.); labinyma@gmail.com (C.E.) \\ 8 Multidisciplinary Centre for Technological Investigations (CEMIT), General Directorate of Scientific and \\ Technological Research (DGICT), National University of Asunción (UNA), 2169 San Lorenzo, Paraguay; \\ cemit@rec.una.py (G.A.B.); cavalos@rec.una.py (C.R.Á.); iperalta@rec.una.py (I.P.) \\ 9 Department of Fishing and Aquaculture, Faculty of Veterinary Sciences (FCV), National University of \\ Asunción (UNA), 2169 San Lorenzo, Paraguay; minsaurralde@vet.una.py \\ 10 Department of Botany, Faculty of Chemical Sciences (FCQ), National University of Asunción (UNA), \\ 2169 San Lorenzo, Paraguay; fmereles@sce.cnc.una.py \\ * Correspondence: marco.toffolon@unitn.it; Tel.: +39-0461-282480
}

Received: 22 May 2018; Accepted: 29 June 2018; Published: 11 July 2018

Abstract: Ypacaraí Lake is the most renowned lake in landlocked Paraguay and a major source of drinking and irrigation water for neighbouring towns. Beyond its socioeconomic and cultural significance, it has great ecological importance, supporting a rich biodiversity. Rapid growth of human presence and activities within its basin has led to its environmental degradation, a heartfelt matter of high political concern that compels intervention. Here, by reconstructing the history of scientific and management-oriented research on this system, we provide a comprehensive assessment of current knowledge and practice to which we contribute our recent, novel findings. An upward trend in total phosphorus concentration confirms ongoing eutrophication of an already eutrophic system, evidenced by consistently high values of trophic state indices. Downward trends in water transparency and chlorophyll-a concentration support the hypothesis that primary production in this lake is fundamentally light limited. Statistical and other analyses suggest high sensitivity of the system to hydraulic, hydro-morphological and hydro-meteorological alterations arising, respectively, from engineering interventions, land use and climate change. By discussing knowledge gaps, opportunities for research and challenges for management and restoration, we argue that this case 
is of high scientific value and that its study can advance theoretical understanding of shallow subtropical lakes.

Keywords: turbid lake; subtropical lake; alternative stable states; limnological study; historical reconstruction; cyanobacterial bloom; light limitation; trend analysis; correlation analysis; PCA

\section{Introduction}

With a surface area of approximately $60 \mathrm{~km}^{2}$, an average depth of $1.72 \mathrm{~m}$, and a maximum depth of $2.53 \mathrm{~m}$, the shallow Ypacaraí Lake is one of the largest lakes in landlocked Paraguay. Ever-present, through music, in the lives of all Paraguayans, it is also by far the most culturally significant one (see Communication S1 in the Supplementary Materials). Moreover, the lake is a major source of drinking and irrigation water for neighbouring towns, many of which rely on agriculture and livestock farming for their livelihoods. It also has a remarkable tourist appeal due to a great proportion of the country's population being highly concentrated in its vicinity, including that of Asunción, its capital city, whose metropolitan area reaches into the basin of the Salado River, the lake's only natural outflow.

It is, therefore, not surprising that its deteriorating environmental state, signalled by rising pollution and eutrophication, receives a lot of attention in the Paraguayan media (see Table S1 in the Supplementary Materials). This is, in fact, nothing more than a reflection of how heartfelt the matter is for the population of the country, which, in turn, makes it a matter of high political concern for local and national authorities, especially during electoral periods. Furthermore, beyond its recreational, inspirational and political value, this shallow, subtropical lake constitutes a case of potentially high scientific relevance, as it presents a unique combination of natural factors in the context of a rapidly developing country, lying at the very interface of two expanding areas of limnological science, (a) shallow lakes theory and (b) subtropical limnology, which we briefly comment upon in the following paragraphs.

Born out of the theory of alternative stable states, first proposed by Lewontin in 1969 [1], shallow lakes theory has developed considerably since a version of the former for the specific case of shallow lakes was first thoroughly described by Scheffer et al. in 1993 [2] following previous studies [3,4]. The original simple conceptual model illustrated how, in some shallow macrophyte-dominated, clear water lakes, a gradual increase in the concentration of a nutrient results in a progressive loss of the system's resilience to external perturbations, which can thus more easily trigger an abrupt shift to an alternative, phytoplankton-dominated, turbid water state. The latter is, additionally, the only possible state after the nutrient concentration increases above a certain lake-specific threshold that varies with a diverse range of factors such as lake surface area, mean depth, retention time, sediment characteristics, relative extension of surrounding marsh areas and fishing intensity [5]. Once this turbidification threshold is surpassed, the restoration of clear water conditions through reductions of nutrient concentration only (i.e., without the triggering effect of an external perturbation) requires, however, that a different, lower threshold is crossed, below which only the clear water state is possible. This hysteretic response is explained by the stabilising feedbacks between the elements of the system present in each of the two alternative stable states [2].

Continuous research has resulted in further development of this simple conceptual model, which has since evolved into a more complex picture that considers the effects of seasonality, chaotic population dynamics and changing weather conditions [6]. It is now known that regular oscillations between alternative stable states may occur [7]. For some systems, it is better to speak of alternative regimes rather than alternative stable states, as they can present transient unstable conditions over relatively long periods [8]. Additional hydro-morphological factors affecting lake stability are now widely recognised, such as lake size $[5,6,9-11]$, lake depth $[5,6]$, spatial heterogeneity $[6,11,12]$ and internal connectivity [11]. Ecological processes, such as 
complex predator-prey interactions and interspecific competition, can also give rise to alternative regimes [6]. For instance, we can no longer speak simply of macrophyte-dominated shallow temperate lakes, but whether these are rooted angiosperms (flowering plants) or charophytes (e.g., stoneworts) must now be specified [13]. The same is true for phytoplankton, as it is now known that dominance by either green algae or filamentous cyanobacteria can also represent self-stabilising alternative states [14]. Research on tropical and subtropical lakes has resulted in the identification of yet one more alternative stable state, characterised by the dominance of free-floating macrophytes [15], which, in these systems, can have complex effects and an equally or even more important structuring role than that of submerged aquatic vegetation [16].

The need to specify climate zones in the previous paragraph is telling of the fact that extending conclusions across latitudes is not always straightforward $[17,18]$. Climate too plays a fundamental role in determining the structure and functioning of a lake ecosystem and, therefore, whether it will be more or less resilient to external perturbations that can trigger regime shifts $[19,20]$. In this respect, warmer lakes seem to be much more sensitive to effects such as water level changes and water temperature increases, and it is precisely at low latitudes that the extreme rainfall events, floods, droughts and heatwaves that might cause them not only occur cyclically due to large-scale atmospheric patterns like the North Atlantic Oscillation (NAO), the Atlantic Multidecadal Oscillation (AMO) and the El Niño-Southern Oscillation (ENSO), but are also expected to become more frequent in response to global warming [21-23].

Nevertheless, scientific knowledge on warm shallow lakes in Mediterranean, tropical and subtropical regions of the world, is still quite limited compared to the amount of research that has been conducted on shallow lakes in the north temperate region [24]. A few examples of relatively well-studied shallow subtropical lakes are Lake Apopka $[25,26]$ and Lake Okeechobee $[27,28]$ in Florida, USA, and Lake Taihu in Jiangsu, China [29,30]. Examples of less studied shallow subtropical lakes that are, however, geographically closer to Ypacaraí Lake are Lake Mangueira in Brazil [31,32] and, in Uruguay, Lake Rodó [33] and a few others [34-36].

From what is currently known, internal nutrient cycling is relatively more important in warm shallow lakes than in their cold temperate counterparts, where external loading exerts a relatively strong control on in-lake nutrient concentrations, making it harder to restore clear water conditions once the system has shifted to a turbid state [24]. Food webs are substantially different [37], and several critical feedback mechanisms known to stabilise clear water conditions in shallow cold temperate lakes may not be as important or even present in warm tropical and subtropical ones. For instance, the effects of macrophytes on trophic interactions seem to be much more complex in tropical and subtropical lakes, where large numbers of small omnivorous fish live closely associated with them [16]. This compromises their role as daytime refugia for zooplankton, which is, hence, subjected to higher predation pressures [24]. Even when macrophytes are not present, shallow subtropical systems are characterised by a richer diversity of predominantly omnivorous fish species in large numbers and at different life stages, as is the case of Ypacaraí Lake, which we present in this article through a comprehensive, interdisciplinary review that was previously not available in scientific literature.

First, with the aim of characterising the study site, the lake and its basin are described in terms of their geographic location, climate, morphological characteristics and hydro-ecological conditions, including special mention of water quality and biodiversity. The socioeconomic context and both historical and recent anthropic impacts are briefly presented as well.

Next, by summarising the history of scientific and management-oriented research on this lake, we provide a comprehensive view of current knowledge and experience, to which we integrate our recent, novel findings. These result from analyses conducted to (a) better understand changes that have occurred in the system due to hydraulic, hydro-morphological and hydro-meteorological alterations arising, respectively, from engineering interventions, land use and climate change; (b) investigate relationships between limnological variables; (c) shed light on the complex functioning of the system, distinguishing between wet and dry periods to gain insight into its response to rainfall events, 
floods and droughts; and (d) to characterise the recent evolution of the lake's trophic state, as well as the type of nutrient limitation of phytoplankton growth.

Specifically, to address these points, we performed, respectively, (a) time series assembly and analyses of trends of eight selected limnological variables; (b) pairwise Pearson correlation analyses between twelve selected limnological variables; (c) principal component analyses and simple linear regressions; and (d) time series reconstruction of trophic state indices and nutrient limitation assessment.

These results allowed us to identify and assess the main factors affecting primary production in this lake, as well as both specific and general knowledge gaps that relate to its complex hydro-morphological and hydro-ecological conditions, which we then discuss with reference to shallow lakes theory and the state of the art of subtropical limnology. We argue that these gaps, together with the many challenges for the lake's effective management and restoration and the currently favourable political context, configure an ideal scenario for scientific research that is worth exploring.

\section{Materials and Methods}

\subsection{Study Area}

\subsubsection{Location and Climate}

Ypacaraí Lake is a major water body of the Salado River Basin. It is situated between latitudes 25.25 and $25.37^{\circ} \mathrm{S}$ and between longitudes 57.28 and $57.38^{\circ} \mathrm{W}$ in Eastern Paraguay, one of the two main natural regions of the country, separated from each other by the southward-flowing Paraguay River. The lake is located some $30 \mathrm{~km}$ to the east of the historical centre of Asunción, the capital of the country, which is also its largest and most populous city. It's metropolitan area, Greater Asunción, reaches into the basin of the lake (Figure 1).

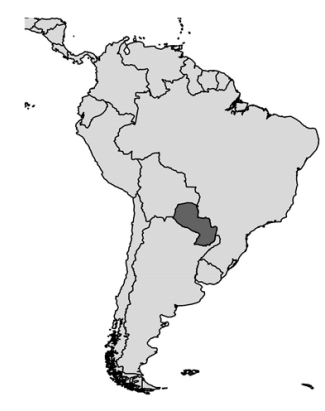

(a)

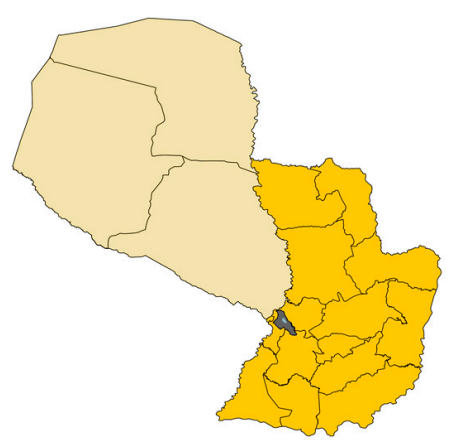

(b)

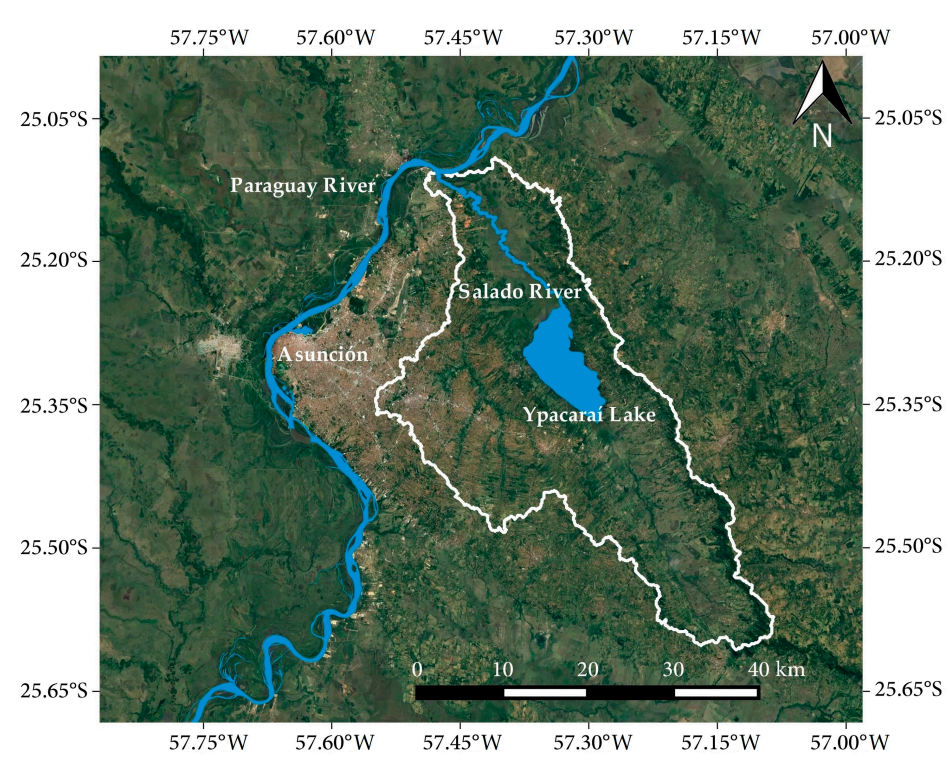

(c)

Figure 1. Location of (a) Paraguay (highlighted in dark grey) in South America; (b) the Salado River Basin (highlighted in dark grey) in Eastern Paraguay (highlighted in dark yellow); (c) satellite image of Ypacaraí Lake, east of Asunción, and the Salado River (its watershed in white), a tributary of the southward-flowing Paraguay River. Image: Google, Terrametrics. 
The entire basin lies within a region whose climate can be characterised as humid subtropical $[38,39]$. The monthly mean air temperature (Figure 2a) ranges from 17 to $27^{\circ} \mathrm{C}$, the warmer period being December-February and the colder period being June-August [40]. The monthly mean precipitations range from $54.0 \mathrm{~mm}$ in July to $174.2 \mathrm{~mm}$ in November (Figure 2b), with mean annual precipitations of about $1300 \mathrm{~mm}$ [40].

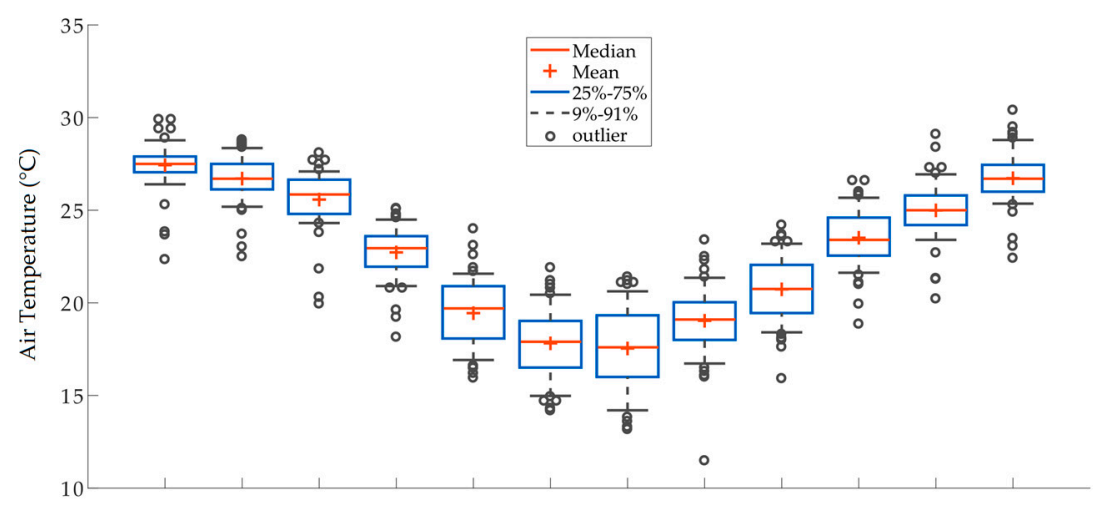

(a)

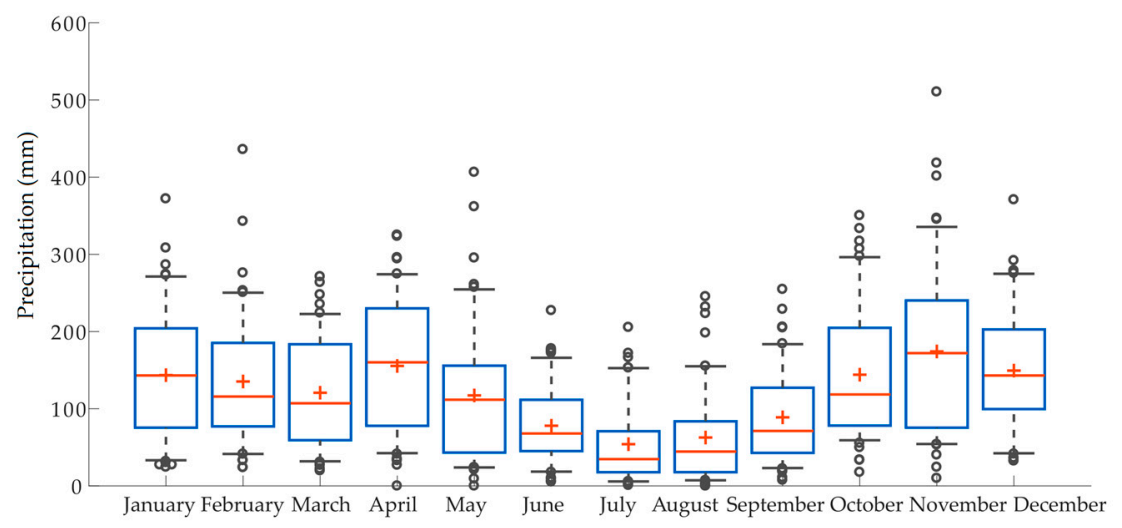

(b)

Figure 2. Climate of the region, characterised by monthly means (1960-2016) of (a) air temperature $\left({ }^{\circ} \mathrm{C}\right)$; and (b) precipitation (mm). Data: Silvio Pettirossi International Airport (AISP) weather station (Luque), Directorate of Meteorology and Hydrology (DMH), Directorate of Civil Aeronautics (DINAC), Paraguay.

The region is periodically subjected to the effects of El Niño-Southern Oscillation (ENSO) [41]. During the warm ENSO phase (El Niño), precipitation, in general, increases, and extreme rainfall events become more frequent [42,43], resulting in major floods of the country's fluvial systems [44]. During the cold ENSO phase (La Niña), opposite patterns are verified, with significant droughts affecting south-eastern Paraguay [45].

Hourly wind data for the town of San Bernardino, on the east shore of the lake, are available starting from 2014, recorded by a weather station located at the San Bernardino Nautical Club (CNSB). A recent study of these data determined that, consistent with regional patterns arising from synoptic-scale atmospheric circulation, prevailing winds in the area blow from the northeast (Figure S1 in the Supplementary Materials) with a mean speed of $2.66 \mathrm{~m} \cdot \mathrm{s}^{-1}$ and a maximum recorded speed of $22.8 \mathrm{~m} \cdot \mathrm{s}^{-1}$. Occasional winds blowing from the south are associated with cold fronts [46]. 


\subsubsection{Morphology and Bathymetry}

Due to important fluctuations of its water level, the gentle slopes of its floodplain and its potentially highly dynamic lakebed, the morphological characteristics of Ypacaraí Lake can vary greatly over time. In Table 1, we refer these characteristics to the mean lake level calculated for 2016-2017 [47,48] and the latest available bathymetric map (Figure 3), elaborated in 2017 after a survey conducted in 2014 [49]. Maximum length and width were calculated as in [50].

Table 1. Morphological characteristics of Ypacaraí Lake under mean lake level conditions (estimated for 2016-2017).

\begin{tabular}{ccc}
\hline Characteristic & Value & Units \\
\hline Gauging station ${ }^{1}$ reference level & 62.28 & $\mathrm{~m}$ a.s.l. \\
Mean lake level & +0.20 & $\mathrm{~m}$ \\
Average depth & 1.72 & $\mathrm{~m}$ \\
Maximum depth & 2.53 & $\mathrm{~m}$ \\
Maximum length & 14 & $\mathrm{~km}$ \\
Maximum width & 6 & $\mathrm{~km}$ \\
Surface area & 60 & $\mathrm{~km}^{2}$ \\
Stored water volume & $101 \times 10^{6}$ & $\mathrm{~m}^{3}$ \\
Shoreline length & 42 & $\mathrm{~km}^{\circ}$ \\
\hline${ }_{1}$ Located at San Bernardino Nautical Club (CNSB, $\left.25.3142^{\circ} \mathrm{S}, 57.2967^{\circ} \mathrm{W}\right)$.
\end{tabular}

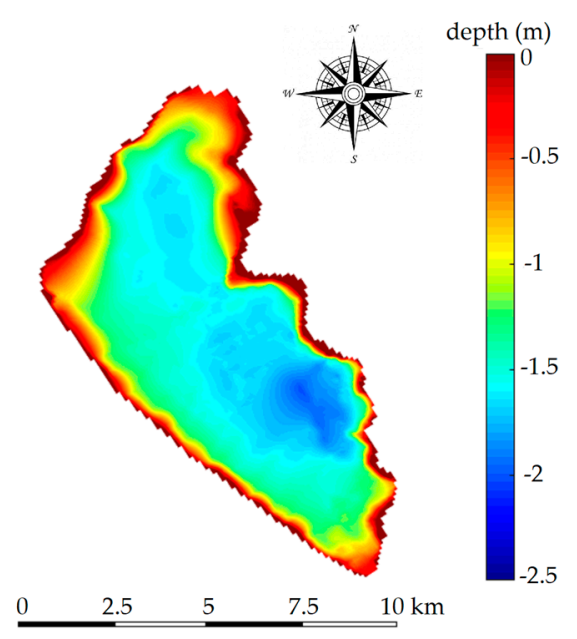

Figure 3. Latest available bathymetric map of Ypacaraí Lake, elaborated in 2017 after a bathymetric survey conducted in 2014 by the Reservoir Division of the Itaipú Binational Entity. Reference zero at $62.28 \mathrm{~m}$ a.s.l. (CNSB gauging station).

As can be observed in Figure 3, in the central area of the lake the bottom is relatively flat, with a slightly deeper part near its central-eastern shore. No reefs separate this central pelagic zone from the shallower northern, north-western, southern and south-western areas.

\subsubsection{Geological and Hydrological Setting}

Ypacaraí Lake is located in a graben of the same name, between two well-defined blocks that form the edges of the central segment of the Asunción Rift [51]. It has a SE-NW strike, oriented along the Pirayú-Salado fluvial valley, flanked in the east by the Altos Hill Range (Figure 4a), a formation of Ordovician origin (Figure S2a in the Supplementary Materials) and in the west by lesser, sparsely distributed hills. The lake lies on a bed of Quaternary sediments deposited on top of Silurian 
sandstone in the SW and Precambrian granite in the NE (Figure S2a) [52]. The topography of the basin determines five major sub-basins (Figure 4a) whose surface areas we report in Table 2.

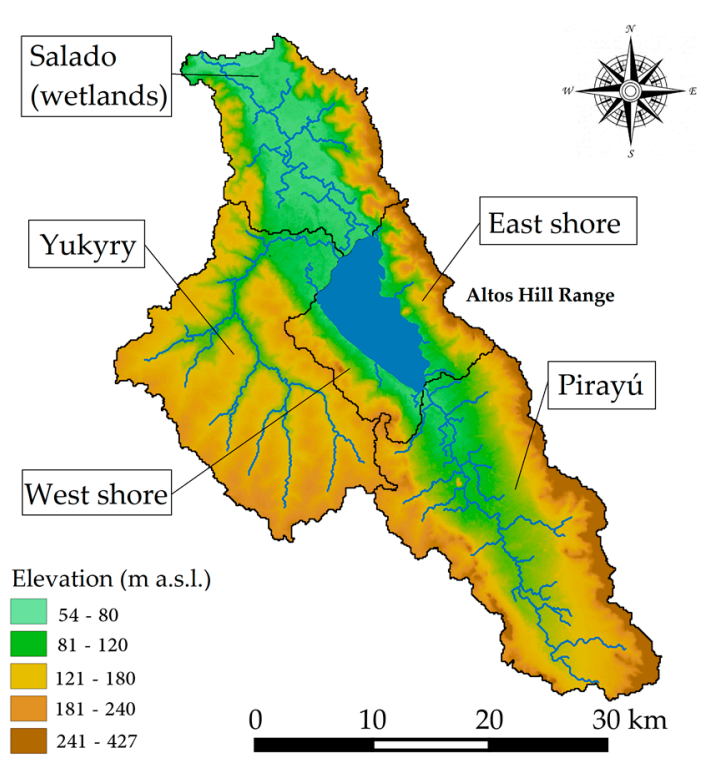

(a)

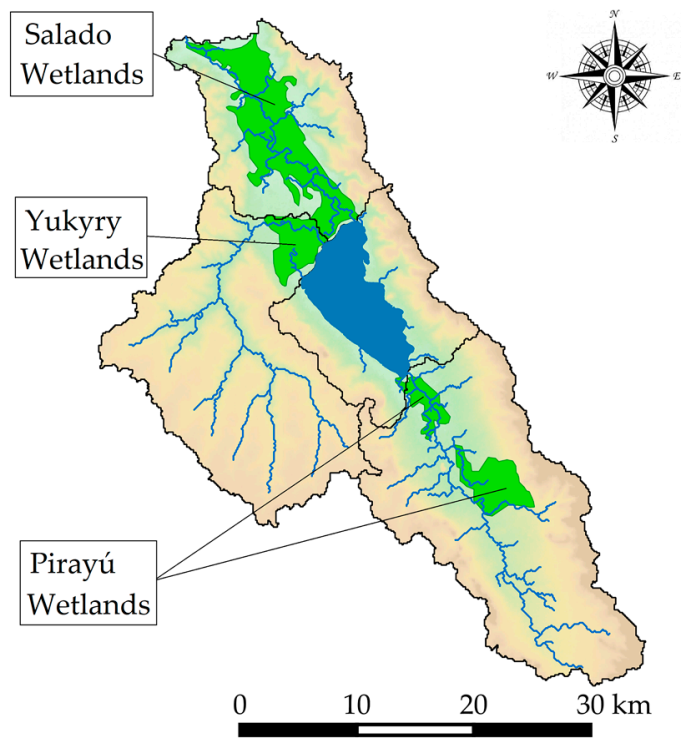

(b)

Figure 4. Thematic maps of the Salado River Basin: (a) topography (digital elevation model elaborated from USGS data, EPSG projection: 32721-WGS84/UTM zone 21S) and major sub-basins; (b) wetlands.

Table 2. Major sub-basins of the Salado River Basin.

\begin{tabular}{cc}
\hline Sub-Basin & Area $\left.\mathbf{( k m}^{\mathbf{2}}\right)$ \\
\hline Pirayú & 367 \\
Yukyry & 343 \\
West shore & 51 \\
East shore & 65 \\
\hline Subtotal & $\mathbf{8 2 6}$ \\
Ypacaraí Lake mean surface area & 60 \\
\hline Ypacaraí Lake (sub-basin) & 886 \\
Salado wetlands (incremental sub-basin) & 203 \\
\hline Salado River Basin & 1089 \\
\hline
\end{tabular}

The Pirayú and Yukyry streams are the main inflows of Ypacaraí Lake. The Pirayú Stream discharges into the lake from its southernmost end, whereas the Yukyry Stream does so through a series of channels distributed along its northern shore, the most important of which we illustrate in Figure 4 . Both streams are hydraulically connected to wetlands, especially and notably in the areas of their mouths (Figure 4b). Of less individual importance, in terms of discharge, are several smaller streams that flow into the lake from its east and west shores (Figure 4a).

The Salado River, a tributary of the Paraguay River, is the lake's only natural outflow. Its hydraulic conditions, which determine water level and lake retention time (mean value estimated to be of approximately 180 days [53,54]), are strongly influenced by the presence of both rooted and free-floating aquatic vegetation and have been substantially modified in recent years by major engineering interventions [55]. Vast marsh areas are also associated with this river (Figure 4b) and are hydraulically connected to those of the Yukyry Stream, adding to the complexity of the lake's hydrological system [53]. 


\subsubsection{Water Quality}

Except for vegetated transition areas, where clear water conditions can be observed (Figure 5a), the water of Ypacaraí Lake is visibly characterised by a brownish colour explained by high concentrations of coloured dissolved organic matter (CDOM) and an elevated turbidity related to wind-induced resuspension of sediments (mainly silt and clay) and the presence of suspended colloidal solids (Figure 5b) [56,57]. Despite the lake's polymictic regime, these light-attenuating conditions have been shown to result in considerable diurnal thermal stratification (Figure 6) [58,59].

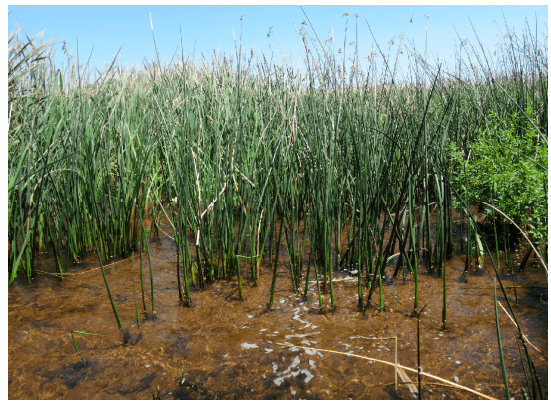

(a)

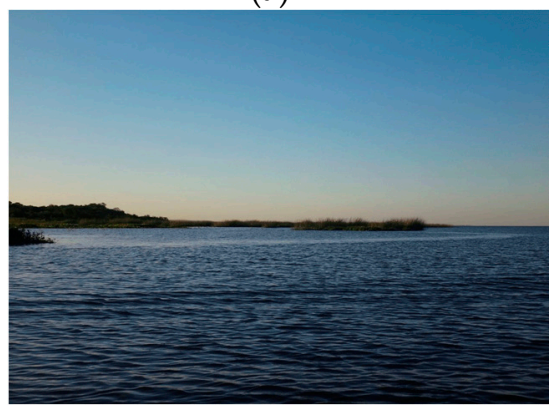

(c)

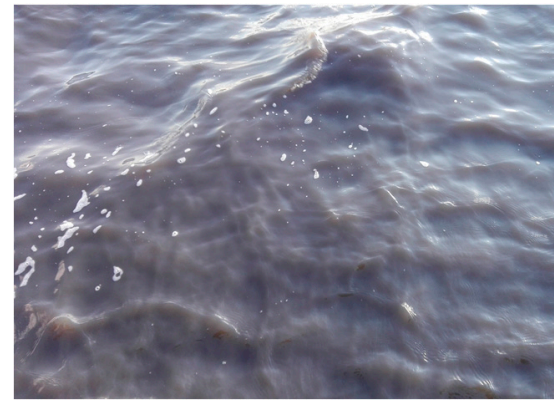

(b)

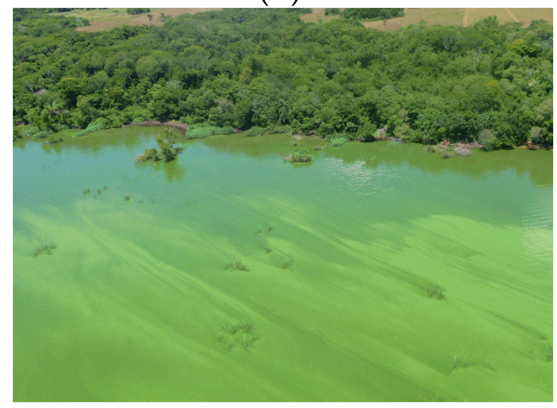

(d)

Figure 5. Contrasting states of Ypacaraí Lake: (a) clear water conditions near the vegetated Yukyry Wetlands; (b) brown turbid water conditions near the non-vegetated east shore; (c) the idyllic blue Ypacaraí Lake, reflecting the colour of the open sky; and (d) the green Ypacaraí Lake during an intense cyanobacterial bloom. Photo credits: (a-c) @ 2017 Andrea Salvadore; (d) @ 2013 Jean Sekatcheff.

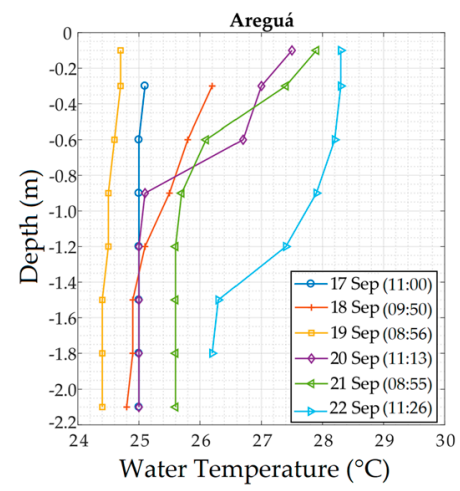

(a)

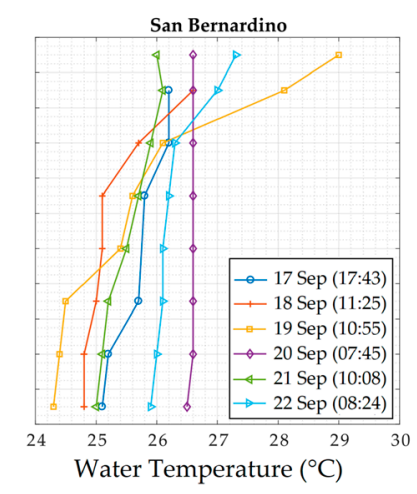

(b)

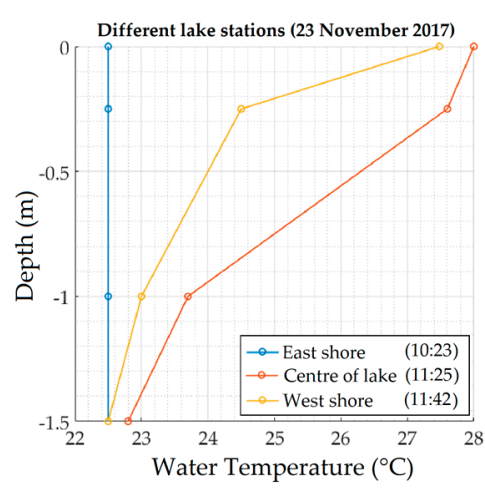

(c)

Figure 6. Vertical profiles of water temperature measured in: (a) September 2015, close to Areguá (west shore); (b) September 2015, close to San Bernardino (east shore); and (c) 23 November 2017, at three different points of the lake. Note that the vertical axes are the same in (a) and (b). 
In Paraguay, the lake is frequently referred to as the 'blue' Ypacaraí Lake, a colour it can indeed present at certain times, when reflecting the open sky (Figure 5c). However, increasing nutrient concentrations over the last decades have recently resulted in intense cyanobacterial blooms (e.g., February 2013) during which the lake can turn deep green (Figure 5d) and oxygen depletion leading to fish kills can occur $[60,61]$.

In the past, phytoplankton blooms were hypothesised to be limited by phosphorus due to the presence of trivalent iron $\left(\mathrm{Fe}^{3+}\right)$, detected in the water column as early as 1937, in colloidal forms (reported in [56]), as well as in the interstitial water of the sediments [57]. Microbiological parameters (e.g., faecal coliforms) are reportedly within acceptable limits [55], as are heavy metals which have not been detected to date in high concentrations in the water $[55,60,61]$ or in the sediments $[52,55,60]$. Ecotoxicological effects of the lake's water have, however, been reported [62] and may very well be related to the presence of pesticides, detected in 2001 in both the lake and its tributary streams [63]. Further information on water quality can be found in references $[55,60,61]$.

\subsubsection{Biodiversity}

Ypacaraí Lake supports a rich diversity of fish that includes at least 75 species, with predominance of Siluriformes (catfish, 32 species) and Characiformes (characins, 24 species), followed by Perciformes (perch-like fish, 9 species) and Gymnotiformes (South American knifefish, 5 species), which occupy several trophic levels [64]. Although not dominant, the presence of the invasive Oreochromis niloticus (Nile tilapia) is to be noted [64]. A detailed list of fish species of the lake can be found in Table S2 in the Supplementary Materials.

Phytoplankton is less diverse (see Table S3a-e in the Supplementary Materials). Diatoms (notably, Aulacoseira granulata) generally dominate in winter [65]. Also, in colder months, blooms of chlorophytes (green algae), cryptophytes and euglenids have been documented, the latter two notably dominating in autumn. In June 2017, a bloom of the dinoflagellate Ceratium furcoides, which is invasive in South America, was also reported for the first time [66].

Cyanobacteria include at least 29 species belonging to 15 genera (Table S3d), all of which are potential toxin producers [65]. Notable examples are species of the genera Microcystis (e.g., Microcystis aeruginosa, Microcystis wesenbergii and Microcystis protocystis) and Anabaena (e.g., Anabaena spiroides and Anabaena circinalis), and the invasive Cylindrospermopsis raciborskii. The latter, first detected in the country in 2005, in the Paraná and Paraguay rivers (in low concentrations of less than 2000 cells $\cdot \mathrm{mL}^{-1}$ ), began blooming in the lake, during warmer months, starting from October 2012 [67]. During these blooms, the species represents between $76.1 \%$ and $98.8 \%$ of phytoplankton samples. A maximum concentration of 833,948 cells $\cdot \mathrm{mL}^{-1}$ was recorded in March 2014 near the Salado River [60]. Cylindrospermopsis raciborskii blooms have since been observed to be consistently followed by blooms of Microcystis aeruginosa, the cyanobacteria that previously dominated the lake during summer [65].

Benthic macroinvertebrates have reportedly disappeared from the sediments of the lake following these recent dramatical cyanobacterial blooms. First, chironomids, which, in 2012, accounted for $40 \%$ to $80 \%$ of benthos samples, were replaced by Hirudinea (leeches) and Hydracarina (water mites) species, which eventually disappeared as well. Starting from February 2015, until today, benthic macroinvertebrates are no longer found in the sediments of Ypacaraí Lake [61,67].

Zooplankton diversity is reportedly low and appears to be decreasing [60,61,68-70]. In 1983-1985, 23 species of rotifers were identified [69], whereas, in 2016, this number decreased to 10 [61]. In both periods, the most abundant rotifer species was Keratella americana. Crustaceans include 10 genera of cladocerans, belonging to 6 families, with preponderance of Daphnia species. Copepods are much less diverse [67]. A detailed list of zooplankton species can be found in Table S4 (Supplementary Materials).

Meiofauna reported in the water bodies of the basin comprise several species of annelids (oligochaetes and leeches), arthropods (crustaceans, insects and mites) and molluscs [70]. Among the latter, it is important to mention the invasive species Limnoperna fortunei (golden mussel), native to 
China, that has invaded Paraguayan waters, of which Ypacaraí Lake is no exception, starting, at least, from the late 1990s [71].

As for vegetation, different soil types and their distribution at the basin scale (Figure S2b in the Supplementary Materials) configure a patchwork of three main formation types: forests, savannas and marshes. Their historical evolution has been well described in works dating back to the early 1980s [72-75]. Despite all three types of formations being in receding and/or deteriorating states, their study has been notably discontinued in the last decades [76].

Aquatic vegetation includes perennials, such as the free-floating Eichornia crassipes and Pistia stratiotes, floating-leaved Eichornia azurea and Victoria cruziana and emergent Thalia geniculata, Typha domingensis, Cyperus giganteus, Schoenoplectus californicus, Ludwigia peploides and Ludwigia bonariensis. Some of these species are recognised to be invasive outside of their native ranges. In the less deteriorated areas, submerged macrophytes, such as the freely suspended Utricularia foliosa and the rooted Cabomba caroliniana can still be found [76].

As a final note on the ecological value of Ypacaraí Lake, in particular, and the Salado River Basin in general, we can mention a wide variety of birds, with at least 83 species being present, some of which are migratory $[70,77]$. Other landmark animal species are the capybara (Hydrochoerus hydrochaeris), the largest living rodent in the world, and the broad-snouted caiman or yacaré (Caiman latirostris) [70].

\subsubsection{Socioeconomic Context and Anthropic Impacts}

The ongoing expansion of the Metropolitan Area of Asunción (Figure 7) implies an exponential increase in the number of people living in the basin, which grew from 207,000 inhabitants in 1988 to $1,470,000$ inhabitants in 2012 [55,78]. It is also important to consider the floating population of tourist destinations, such as the town of San Bernardino (see Figure S2c), a town of about 10,000 permanent residents on the east shore of the lake, whose actual population can grow up to 100,000 inhabitants in summer months [55], numbers that are only expected to increase in the future. During this high season, recreational activities, such as bathing, swimming and angling, as well as water sports (e.g., jet skiing) and motorboat sightseeing excursions are likely having an underestimated impact [79].

A range of factors contribute to most domestic and industrial wastewaters being either disposed of through septic tanks or discharged without any treatment into the many streams of the basin. The first results in the pollution of the subjacent aquifers, especially Aquifer Patiño (Figure S3 in the Supplementary Materials), whereas the second results in the pollution of surface waters, including Ypacaraí Lake. These factors include: (a) increasing population densities resulting from progressive unplanned urbanisation, especially of the Yukyry sub-basin; (b) a high administrative fragmentation (21 municipalities in the basin, as shown in Figure S2c); (c) the institutional complexity that characterises the country (many institutions with overlapping responsibilities) [55]; (d) insufficient infrastructure to provide adequate sanitation (less than $5 \%$ of wastewaters are treated [55]); and (e) the lack of enforcement of environmental regulations.

Untreated wastewaters of domestic and industrial origin have been recently estimated to account for about $57 \%$ of nutrients that would presently be entering surface waters in the basin [55]. Mostly concentrated in the Pirayú sub-basin (Figure S2d), livestock farming is estimated to account for $33 \%$ of nitrogen and $37 \%$ of phosphorus loads reaching the streams. Accounting for the remaining part would be the nutrient compounds present in fertilisers used in crop fields, also concentrated in the Pirayú sub-basin, a notable exception being strawberry cultivation in Areguá (Figure S2c), and diffuse sources, reportedly reaching surface waters in progressively higher proportions following the heavy deforestation that occurred in the basin between 1975 and 1985 [54]. 

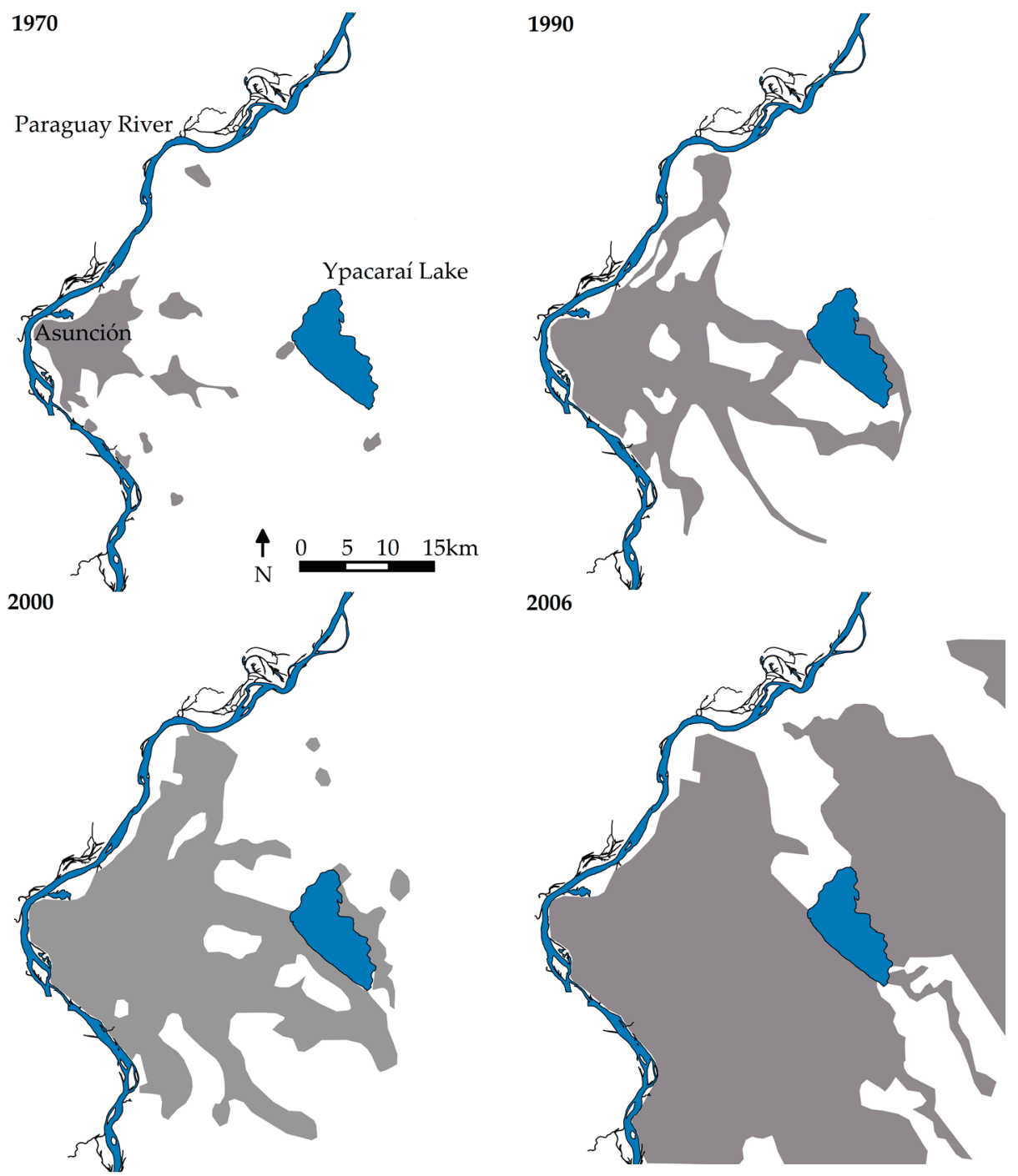

Figure 7. Urban expansion in the region between 1970 and 2006, redrawn from the one reported in the Metropolitan Strategic Plan for Asunción of the Ministry of Public Works and Communications of Paraguay (MOPC, 2012) [80].

In total, nutrient loads effectively reaching the lake after natural depuration of its inflows have been estimated to be 475 tons per year of nitrogen, and 45 tons per year of phosphorus, with untreated domestic wastewaters respectively accounting for $40 \%$ and $24 \%$ of these loads. Livestock farming would be accounting for $28 \%$ of the P-load and $56 \%$ of the N-load [81].

In this respect, it is important to mention the depurative role of wetland areas, which is also briefly described in Communication S2 (Supplementary Materials). Reportedly, 26\% of these areas were lost between 2005 and 2015 [55] as a consequence of urban expansion and, more recently, the construction, north of the lake, of a highway connecting the city of Luque to the town of San Bernardino [55]. As part of this project, four new concrete bridges were built over the main channel and three anabranches of the Salado River, a major engineering intervention whose impacts on the hydraulic regime of the system and, consequently, on the lake's retention time, are yet to be assessed.

\subsection{Previous Studies and Projects, and Datasets}

Multiple documents resulting from previous studies and projects, including research articles and technical reports, most of which are only available in Spanish, have been collected and reviewed to 
reconstruct the history of scientific and management-oriented research on this lake. A list is provided, for further reference, in Table S5 (Supplementary Materials).

This review led to the identification of several datasets from both concluded and ongoing measurement campaigns. The more complete and robust of these datasets, in terms of number of variables that were measured and number of measurements available for each variable, were then selected for the statistical and other analyses reported herein (Table 3).

In all cases, samples/measurements were collected/taken near the water surface. The sampling/measurement frequencies of the Japan International Cooperation Agency (JICA), Multidisciplinary Centre for Technological Investigations (CEMIT) of the National University of Asunción (UNA) I and CEMIT-UNA II datasets were variable and are illustrated in Table S6a-c (Supplementary Materials). Lake stations corresponding to these datasets are illustrated in Figure S4 (Supplementary Materials). Limnological variables are measured by Itaipú sensors (CIH-Itaipú dataset) at a 20-min temporal resolution at several points of interest of the Salado River Basin. Data from three of these stations, the ones located inside the lake (Figure S4), were used in this study. The National Navigation and Ports Administration of Paraguay (ANNP) records the lake level (CNSB gauging station) on a daily basis, and the DMH-DINAC measures meteorological variables (AISP weather station) every $10 \mathrm{~min}$.

Table 3. Selected datasets used in this study.

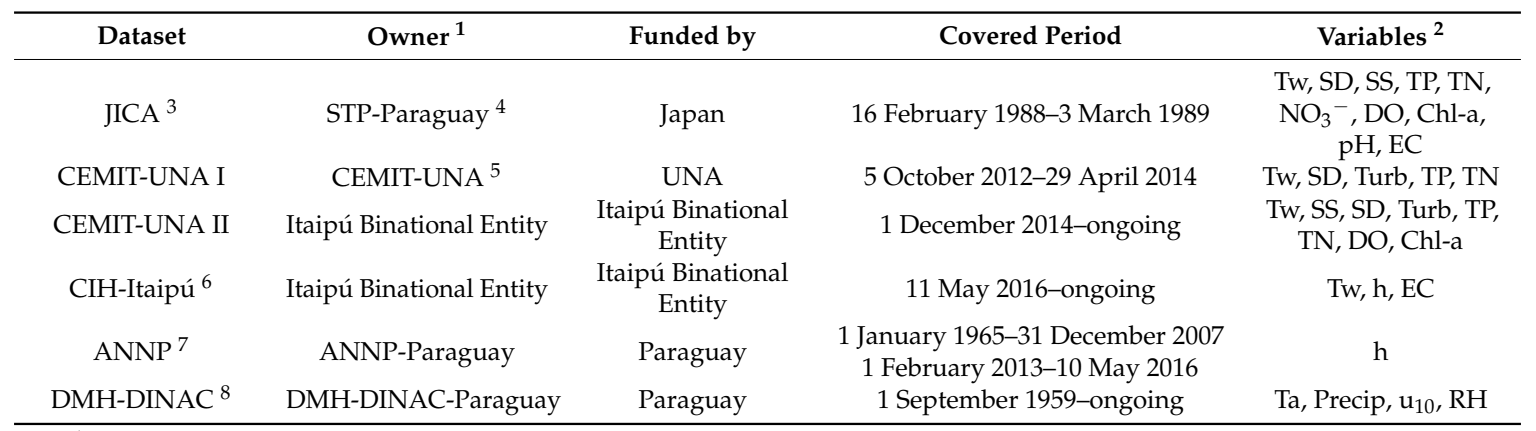

${ }^{1}$ All datasets used in this study are publicly available, as they are owned by either a government agency (STP, ANNP and DMH-DINAC), an academic institution (CEMIT-UNA) or a binational entity (Itaipú Binational Entity); ${ }^{2}$ Variables: water temperature (Tw), lake level (h), Secchi depth (SD), concentration of suspended solids (SS), total phosphorus concentration (TP), total nitrogen concentration (TN), concentration of nitrates $\left(\mathrm{NO}_{3}{ }^{-}\right)$, dissolved oxygen concentration (DO), chlorophyll-a concentration (Chl-a), electrical conductivity (EC), air temperature (Ta), precipitation (Precip), wind speed at $10 \mathrm{~m}$ above the water surface $\left(\mathrm{u}_{10}\right)$ and relative humidity (RH); ${ }^{3}$ Japan International Cooperation Agency (JICA); ${ }^{4}$ Technical Secretariat of Planning of Paraguay (STP);

${ }^{5}$ Multidisciplinary Centre for Technological Investigations (CEMIT) of the National University of Asunción (UNA);

${ }^{6}$ International Hydroinformatics Centre $(\mathrm{CIH}) ;{ }^{7}$ National Navigation and Ports Administration of Paraguay (ANNP); ${ }^{8}$ Directorate of Meteorology and Hydrology (DMH) of the National Directorate of Civil Aeronautics of Paraguay (DINAC).

\subsection{Statistical and Other Methods}

\subsubsection{Time Series Assembly and Trend Analyses}

As a first approximation to assess major limnological changes that might have occurred between the late 1980s (1988-1989) and the last few years (2012-2017), arithmetic means and standard deviations were calculated for each period/dataset for eight selected limnological variables: water temperature (Tw), lake level (h), Secchi depth (SD), and the concentrations of suspended solids (SS), total phosphorus (TP), total nitrogen (TN), dissolved oxygen (DO) and chlorophyll-a (Chl-a). When data from multiple lake sampling/monitoring stations were available for a given time, these were first spatially averaged to account for overall lake conditions.

For all eight variables, time series were assembled from multiple datasets, provided they were directly comparable (same or analogous/equivalent variables and measurement instruments/methods). Nonparametric Mann-Kendall (MK) tests [82] at 95\% confidence levels 
were then performed to assess whether these variables presented significant upward or downward monotonic trends. For this, the Theil-Sen estimator (Sen's slope, S) [83] was used to robustly fit lines to the data, and the Kendall rank correlation coefficient (Kendall's $\tau$ ) [84] was calculated to determine whether these trends were positive or negative.

\subsubsection{Pairwise Pearson Correlation Analyses}

Pairwise Pearson correlation analyses at $95 \%$ and $99 \%$ confidence levels were performed on twelve selected limnological variables of two composite datasets, DS1 (JICA/ANNP/DMH-DINAC) and DS2 (CEMIT-UNA II/ANNP/CIH-Itaipú/DMH-DINAC), corresponding, respectively, to two different periods, 1988-1989 and 2014-2017.

Variables in DS1 included: Tw, h, SD, SS, TP, TN, $\mathrm{NO}_{3}{ }^{-}, \mathrm{Chl}-\mathrm{a}, \mathrm{DO}, \mathrm{pH}$, electrical conductivity (EC) and daily cumulative rainfall (CumRain) which was calculated from high-resolution (10 min) precipitation data. Variables in DS2 were the same, with the addition of water turbidity (Turb), which, in the case of this dataset, was used instead of SS in this and the following analyses.

\subsubsection{Principal Component Analyses and Simple Linear Regressions}

Principal component analyses (PCAs) were performed on the same two composite datasets, DS1 and DS2, to assess which limnological variables were most influential in determining the overall conditions of the lake at any given time (i.e., those most strongly correlated with the two main principal components, explaining together most of the variance in each dataset). Points were classified as wet or dry depending on whether a cumulative rainfall of more than $30 \mathrm{~mm}$ was recorded or not within $24 \mathrm{~h}$ prior to the sampling/measurement time.

Additionally, to provide information on the relative importance of evaporation in the water balance of the lake, two-week evaporation volumes (Ev), in $\mathrm{mm}$, were estimated for a thirteen-month period (1 September 2016 to 30 September 2017) using a simplified Dalton-type approach $[85,86]$. Simple linear regressions were then performed between electrical conductivity (EC) and lake level (h), and between EC and Ev.

\subsubsection{Time Series Reconstruction of Trophic State Indices and Nutrient Limitation Assessment}

Time series of trophic state indices (TSI) were reconstructed for the 1988-2017 period, starting from SD, Chl-a, TP and TN data (JICA, CEMIT-UNA I and CEMIT-UNA II datasets). For the first three indices, modified versions (MTSI) of the original formulations by Carlson [87] have been proposed for tropical and subtropical lakes [88-91], motivated by the typical differences these systems present with respect to temperate ones, such as generally higher turbidity (and consequently, generally lower Secchi depths) throughout the entire year [92].

In this study, the modified Equations (1)-(3), as in [88,89], were used:

$$
\begin{gathered}
\text { MTSI }(\mathrm{TP})=10[6-\ln (80.32 / \mathrm{TP}) / \ln 2], \\
\text { MTSI }(\mathrm{SD})=10[6-(0.64+\ln \mathrm{SD}) / \ln 2], \\
\text { MTSI }(\text { Chl-a })=10[6-(2.04-0.695 \ln \text { Chl-a }) / \ln 2] .
\end{gathered}
$$

For each variable, the lake's trophic state was characterised, as in [89], according to the following limits: ultra-oligotrophic $\leq 24 ; 24<$ oligotrophic $\leq 44 ; 44<$ mesotrophic $\leq 54 ; 54<$ eutrophic $\leq 74$; hyper-eutrophic $>74$.

For the index based on total nitrogen, Equation (4) (originally proposed in 1981 by Kratzer and Brezonik) [93], was used:

$$
\mathrm{TSI}(\mathrm{TN})=10[6-\ln (1.47 / \mathrm{TN}) / \ln 2] \text {. }
$$

TSI (TN) classifies the trophic state of the system as follows: ultra-oligotrophic $\leq 29$; $29<$ oligotrophic $\leq 49 ; 49<$ mesotrophic $\leq 54 ; 54<$ eutrophic $\leq 58$; hyper-eutrophic $>58$. 
Finally, to assess the degree of nitrogen over phosphorus limitation over the last thirty years, we reconstructed the time series of (a) the difference between the corresponding trophic state indices, TSI (TN)-TSI (TP); and (b) the TN to TP ratio. As done for the other time series, MK tests at $95 \%$ confidence level were performed on these two.

In the case of difference (a), consistently negative values of TSI (TN)-TSI (TP) indicate nitrogen limitation, while consistently positive values indicate phosphorus limitation. Values oscillating around zero indicate co-limitation by both nutrients. Note that, for methodological consistency, for this analysis, we recalculated the trophic state index for total phosphorus as in reference [94], given by Equation (5):

$$
\text { TSI }(\mathrm{TP})=10[6-\ln (48 / \mathrm{TP}) / \ln 2] .
$$

In the case of ratio (b), we compared TN:TP values to the mass-based Redfield ratio (7.2:1, as in reference [95]), corresponding to the classical atomic Redfield ratio of 16:1 [96], above which, limitation is given by phosphorus, and below which, limitation is given by nitrogen.

\section{Results}

\subsection{Scientific and Management-Oriented Research History}

The history of scientific and management-oriented research on this lake has been summarised and is presented in Appendix A. A timeline of major studies and projects, reflecting this history, is also included for illustrative purposes (Figure 8).

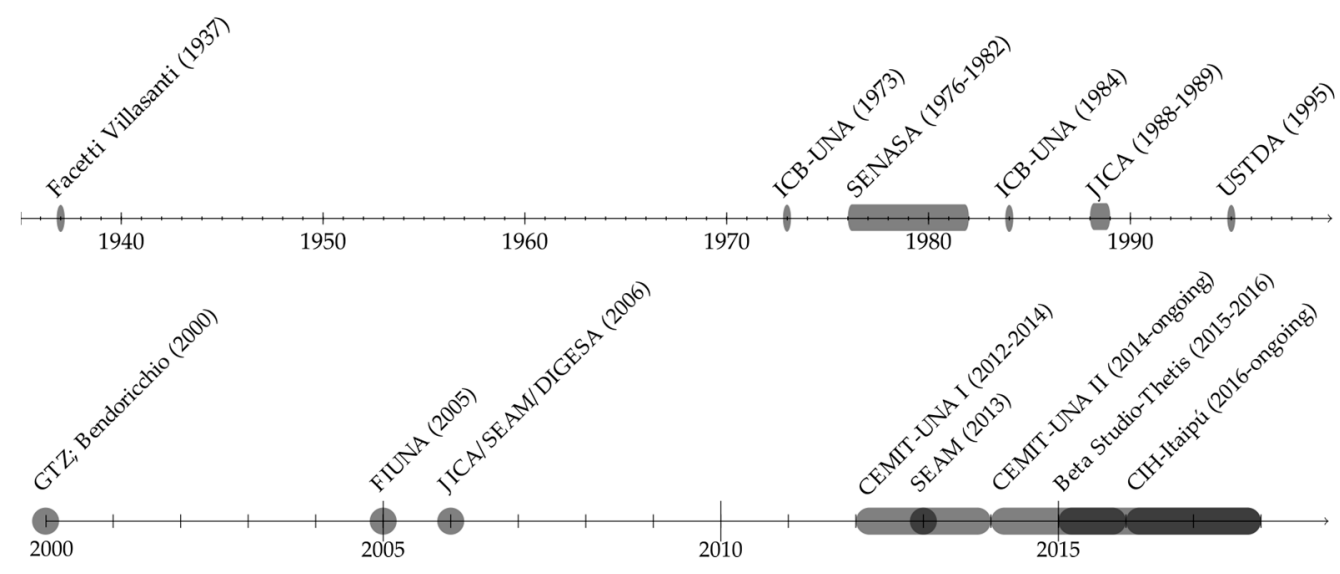

Figure 8. Timeline of studies and projects reflecting the history of scientific and management-oriented research on Ypacaraí Lake.

\subsection{Statistical and Other Analyses}

\subsubsection{Time Series Assembly and Trend Analyses}

Time series of eight selected limnological variables were assembled with data from multiple datasets covering two selected periods: 1988-1989 (JICA and ANNP) and 2012-2017 (CEMIT-UNA I, CEMIT-UNA II, ANNP and CIH-Itaipú) (Figure 9a-h). Calculated arithmetic means and standard deviations of all eight variables for the two selected periods as well as trend statistics (Kendall's $\tau$ and Sen's slope, $S$ ) that were found to be significant (at a 95\% confidence level) are shown in Table 4. 


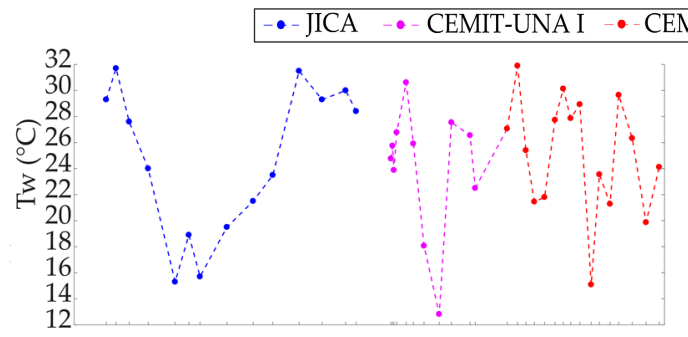

(a)

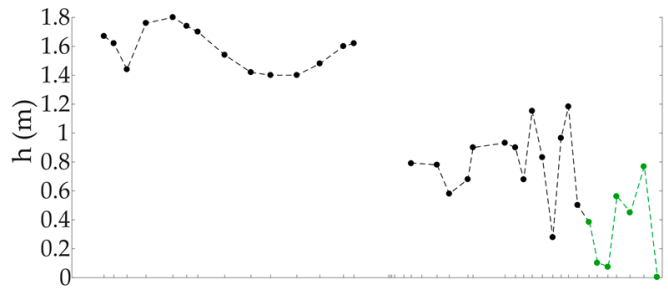

(b)

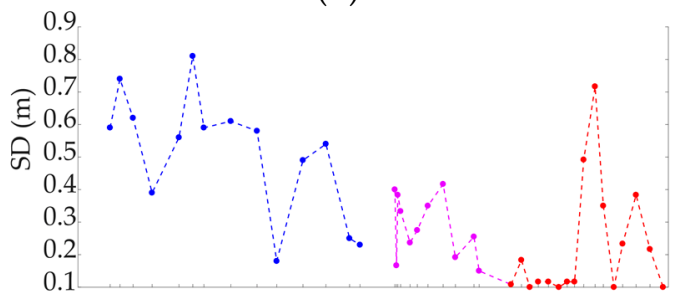

(c)

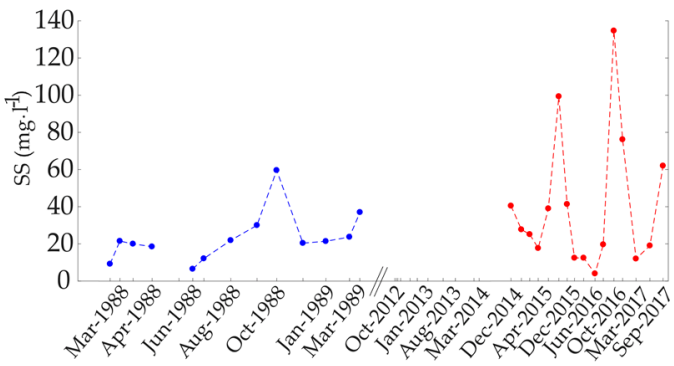

(d)

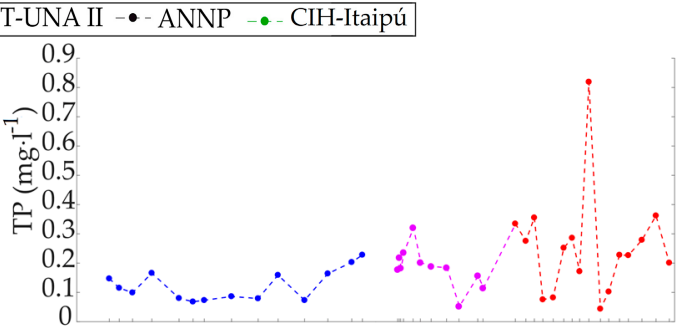

(e)

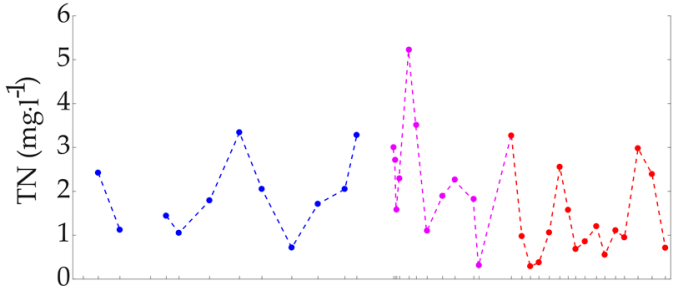

(f)

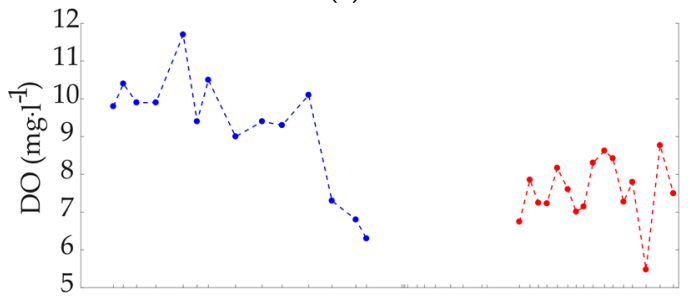

(g)

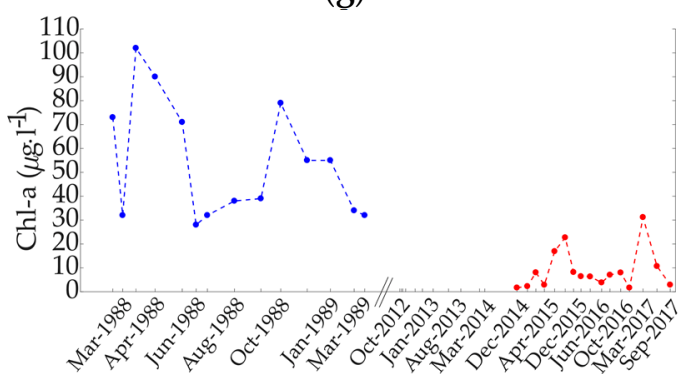

(h)

Figure 9. Time series of eight selected limnological variables of Ypacaraí Lake: (a) water temperature $\left({ }^{\circ} \mathrm{C}\right) ;(\mathbf{b})$ lake level (m); (c) Secchi depth (m); (d) concentration of suspended solids $\left(\mathrm{mg} \cdot \mathrm{L}^{-1}\right)$; (e) total phosphorus concentration $\left(\mathrm{mg} \cdot \mathrm{L}^{-1}\right)$; (f) total nitrogen concentration $\left(\mathrm{mg} \cdot \mathrm{L}^{-1}\right) ;(\mathrm{g})$ dissolved oxygen concentration $\left(\mathrm{mg} \cdot \mathrm{L}^{-1}\right)$; and $(\mathbf{h})$ chlorophyll-a concentration $\left(\mu \mathrm{g} \cdot \mathrm{L}^{-1}\right)$. Note that the temporal axes are separated into two periods (1988-1989 and 2012-2017).

Significant downward trends in lake level, Secchi depth, dissolved oxygen and chlorophyll-a were found as well as a significant upward trend in total phosphorus, all of which were also evidenced by noticeable changes in the arithmetic means calculated for each period. Although no significant trend was identified for the concentration of suspended solids, its arithmetic mean almost doubled and its variability greatly increased between 1988-1989 and 2014-2017. 
Table 4. Arithmetic means, standard deviations and trend statistics (Kendall's $\tau$ and Sen's slope, $S$ ) of eight selected variables of Ypacaraí Lake.

\begin{tabular}{|c|c|c|c|c|c|}
\hline Variable (Units) ${ }^{1}$ & Dataset $^{2}$ & $\begin{array}{l}\text { Arithmetic } \\
\text { Mean }\end{array}$ & $\begin{array}{c}\text { Standard } \\
\text { Deviation }\end{array}$ & Kendall's $\tau$ & Sen's Slope, $S$ \\
\hline \multirow[b]{2}{*}{$\operatorname{Tw}\left({ }^{\circ} \mathrm{C}\right)$} & JICA & 24.7 & 5.75 & \multirow[b]{2}{*}{ n.s. ${ }^{3}$} & \multirow[b]{2}{*}{ n.s. } \\
\hline & CEMIT-UNA I/II & 24.7 & 4.76 & & \\
\hline \multirow{2}{*}{$\mathrm{h}(\mathrm{m})$} & ANNP & 1.59 & 0.140 & \multirow{2}{*}{-0.654} & \multirow{2}{*}{-338} \\
\hline & ANNP/CIH-Itaipú & 0.643 & 0.336 & & \\
\hline \multirow{2}{*}{$\mathrm{SS}\left(\mathrm{mg} \cdot \mathrm{L}^{-1}\right)$} & JICA & 23.2 & 13.6 & \multirow{2}{*}{ n.s. } & \multirow{2}{*}{ n.s. } \\
\hline & CEMIT-UNA II & 40.2 & 36.1 & & \\
\hline \multirow{2}{*}{$\mathrm{SD}(\mathrm{m})$} & JICA & 0.513 & 0.187 & \multirow{2}{*}{-0.482} & \multirow{2}{*}{-392} \\
\hline & CEMIT-UNA I/II & 0.248 & 0.152 & & \\
\hline \multirow{2}{*}{$\mathrm{TP}\left(\mathrm{mg} \cdot \mathrm{L}^{-1}\right)$} & JICA & 0.124 & 0.0531 & \multirow{2}{*}{+0.315} & \multirow{2}{*}{+258} \\
\hline & CEMIT-UNA I/II & 0.227 & 0.148 & & \\
\hline \multirow{2}{*}{$\mathrm{TN}\left(\mathrm{mg} \cdot \mathrm{L}^{-1}\right)$} & JICA & 1.91 & 0.854 & \multirow{2}{*}{ n.s. } & \multirow{2}{*}{ n.s. } \\
\hline & CEMIT-UNA I/II & 1.75 & 1.19 & & \\
\hline \multirow{2}{*}{$\mathrm{DO}\left(\mathrm{mg} \cdot \mathrm{L}^{-1}\right)$} & JICA & 9.27 & 1.50 & \multirow{2}{*}{-0.394} & \multirow{2}{*}{-171} \\
\hline & CEMIT-UNA II & 7.57 & 0.824 & & \\
\hline \multirow{2}{*}{ Chl-a $\left(\mu \mathrm{g} \cdot \mathrm{L}^{-1}\right)$} & JICA & 54.3 & 24.6 & \multirow{2}{*}{-0.589} & \multirow{2}{*}{-445} \\
\hline & CEMIT-UNA II & 9.25 & 6.41 & & \\
\hline
\end{tabular}

1 Water temperature (Tw), lake level (h), concentration of suspended solids (SS), Secchi depth (SD), total phosphorus concentration (TP), total nitrogen concentration (TN), dissolved oxygen concentration (DO), chlorophyll-a concentration (Chl-a); ${ }^{2}$ JICA (1988-1989); CEMIT-UNA I (2012-2017); CEMIT-UNA II (2014-2017); ANNP (1988-2016); CIH-Itaipú (2016-2017); ${ }^{3}$ n.s. non-significant.

\subsubsection{Pairwise Pearson Correlation Analyses}

Pairwise Pearson correlation coefficients between the twelve limnological variables of interest were calculated for two different periods, 1988-1989 (Table 5) and 2014-2017 (Table 6). For the first period, a significant positive correlation (95\% confidence level) was found between water temperature and electrical conductivity, as well as between chlorophyll-a and $\mathrm{pH}$. Very significant and strong negative correlations (99\% confidence level) were found between (a) lake level and electrical conductivity; (b) Secchi depth and suspended solids; (c) Secchi depth and total phosphorus; and (d) total phosphorus and dissolved oxygen.

Table 5. Pairwise Pearson correlation coefficients for twelve selected limnological variables of Ypacaraí Lake (period 1988-1989) ${ }^{1}$.

\begin{tabular}{|c|c|c|c|c|c|c|c|c|c|c|c|c|}
\hline 1988-1989 & $\mathrm{Tw}$ & h & SD & SS & TP & TN & $\mathrm{NO}_{3}{ }^{-}$ & Chl-a & DO & $\mathrm{pH}$ & EC & CumRain \\
\hline $\mathrm{Tw}$ & 1.00 & -0.43 & -0.48 & 0.22 & 0.54 & 0.12 & 0.26 & 0.29 & -0.51 & -0.27 & $0.65^{2}$ & -0.12 \\
\hline $\mathrm{h}$ & & 1.00 & 0.15 & -0.53 & 0.13 & -0.30 & 0.41 & -0.29 & -0.02 & -0.01 & $-0.79^{3}$ & 0.48 \\
\hline SD & & & 1.00 & -0.76 & -0.82 & -0.25 & -0.28 & -0.17 & 0.49 & 0.47 & $\overline{-0.33}$ & -0.09 \\
\hline SS & & & & $\overline{1.00}$ & $\overline{0.47}$ & 0.48 & -0.14 & 0.24 & -0.27 & -0.17 & 0.41 & 0.16 \\
\hline TP & & & & & 1.00 & 0.35 & 0.54 & 0.08 & -0.80 & -0.31 & 0.01 & 0.15 \\
\hline $\mathrm{TN}$ & & & & & & 1.00 & 0.32 & -0.10 & $\overline{-0.50}$ & 0.13 & -0.02 & -0.31 \\
\hline $\mathrm{NO}_{3}^{-}$ & & & & & & & 1.00 & 0.05 & -0.43 & 0.11 & -0.37 & 0.08 \\
\hline Chl-a & & & & & & & & 1.00 & 0.37 & 0.63 & 0.14 & 0.41 \\
\hline DO & & & & & & & & & 1.00 & 0.44 & -0.03 & -0.23 \\
\hline $\mathrm{pH}$ & & & & & & & & & & 1.00 & -0.42 & 0.22 \\
\hline $\mathrm{EC}$ & & & & & & & & & & & 1.00 & -0.41 \\
\hline CumRain & & & & & & & & & & & & 1.00 \\
\hline
\end{tabular}


Table 6. Pairwise Pearson correlation coefficients for twelve selected limnological variables of Ypacaraí Lake (period 2014-2017) ${ }^{1}$.

\begin{tabular}{|c|c|c|c|c|c|c|c|c|c|c|c|c|}
\hline 2014-2017 & $\mathrm{Tw}$ & h & SD & Turb & TP & TN & $\mathrm{NO}_{3}{ }^{-}$ & Chl-a & DO & $\mathrm{pH}$ & EC & CumRain \\
\hline Tw & 1.00 & 0.26 & -0.35 & 0.28 & 0.45 & 0.08 & 0.04 & 0.00 & -0.37 & -0.47 & -0.07 & -0.12 \\
\hline $\mathrm{h}$ & & 1.00 & -0.29 & -0.31 & -0.01 & 0.01 & -0.19 & -0.18 & -0.16 & -0.34 & $-0.82^{3}$ & -0.32 \\
\hline $\mathrm{SD}$ & & & 1.00 & $-0.62^{2}$ & 0.13 & 0.00 & -0.46 & 0.02 & 0.33 & 0.67 & 0.24 & -0.26 \\
\hline Turb & & & & 1.00 & -0.05 & 0.15 & 0.51 & 0.06 & -0.17 & -0.53 & 0.14 & 0.36 \\
\hline $\mathrm{TP}$ & & & & & 1.00 & 0.16 & -0.05 & 0.01 & 0.01 & -0.07 & 0.05 & -0.04 \\
\hline $\mathrm{TN}$ & & & & & & 1.00 & -0.11 & 0.52 & -0.37 & 0.17 & 0.07 & 0.05 \\
\hline $\mathrm{NO}_{3}{ }^{-}$ & & & & & & & 1.00 & -0.26 & -0.19 & -0.03 & 0.37 & 0.61 \\
\hline Chl-a & & & & & & & & 1.00 & -0.40 & 0.27 & -0.01 & -0.11 \\
\hline $\mathrm{DO}$ & & & & & & & & & 1.00 & 0.18 & -0.03 & -0.18 \\
\hline $\mathrm{pH}$ & & & & & & & & & & 1.00 & 0.46 & 0.17 \\
\hline EC & & & & & & & & & & & 1.00 & 0.50 \\
\hline CumRain & & & & & & & & & & & & 1.00 \\
\hline
\end{tabular}

${ }^{1}$ CEMIT-UNA II: water temperature (Tw), Secchi depth (SD), turbidity (Turb), TP concentration, TN concentration, concentration of nitrates $\left(\mathrm{NO}_{3}{ }^{-}\right)$, chlorophyll-a concentration (Chl-a), dissolved oxygen concentration (DO), $\mathrm{pH}$, electrical conductivity (EC); ANNP: lake level (h); CIH-Itaipú: lake level (h); DMH-DINAC: daily cumulative rainfall (CumRain); ${ }^{2}$ in bold: significant correlation at a $95 \%$ confidence level; ${ }^{3}$ in bold, underlined: significant correlation at a $99 \%$ confidence level.

For the second period, weak but significant positive correlations were found between (a) turbidity and nitrates; (b) total nitrogen and chlorophyll-a; (c) nitrates and daily cumulative rainfall; and (d) electrical conductivity and daily cumulative rainfall. Weak correlations were also found between Secchi depth and $\mathrm{pH}$ (positive, very significant), and between Secchi depth and turbidity (negative, significant). As for the first period, a very significant strong negative correlation was found between lake level and electrical conductivity.

\subsubsection{Principal Component Analyses and Simple Linear Regressions}

The results of the PCAs performed on the same composite datasets, DS1 (1988-1989) and DS2 (2014-2017), are presented in the biplots of Figure 10. For the first period (1988-1989), the first two principal components, PC1 and PC2, explained together $55.6 \%$ of the total variance in the composite dataset. PC1 separated points presenting high water transparency, represented by SD, as well as high $\mathrm{DO}$ and $\mathrm{pH}$, from those presenting low values of these variables. It also separated points with low versus high SS, Tw, TP and TN values. In turn, PC2 separated points with low $\mathrm{h}$ and high EC from those presenting the opposite conditions.

For the second period (2014-2017), the first two principal components, PC1 and PC2, explained together $47.6 \%$ of the total variance in the composite dataset. As for the first period, $\mathrm{PC} 1$ separated points presenting high $\mathrm{SD}, \mathrm{DO}$ and $\mathrm{pH}$ values from those presenting low ones or, respectively and equivalently, points with low versus high turbidity and Tw, as SD decreases with increasing turbidity and oxygen solubility decreases with increasing water temperature. Again, PC2 separated points with low $\mathrm{h}$ and high EC from those presenting the opposite conditions.

These results led to further investigation in the form of two simple linear regressions: (a) between lake level (h; ANNP and CIH-Itaipú datasets) and the concentration of conductive ions, indicated by EC (CEMIT-UNA II dataset); and (b) between two-week cumulative evaporation estimates (Ev) and corresponding two-week means of EC data, which we present in Figure S5 (Supplementary Materials). The analysis revealed that a linear fit may be used to relate EC to $h\left(r^{2}=0.67\right)$ or Ev $\left(r^{2}=0.72\right)$, with root mean squared errors (RMSE) of $18.1 \mu \mathrm{S} \cdot \mathrm{cm}^{-1}\left(11.7 \%\right.$ of the mean value) and $20.8 \mu \mathrm{S} \cdot \mathrm{cm}^{-1}(11.6 \%$ of the mean value), respectively. 


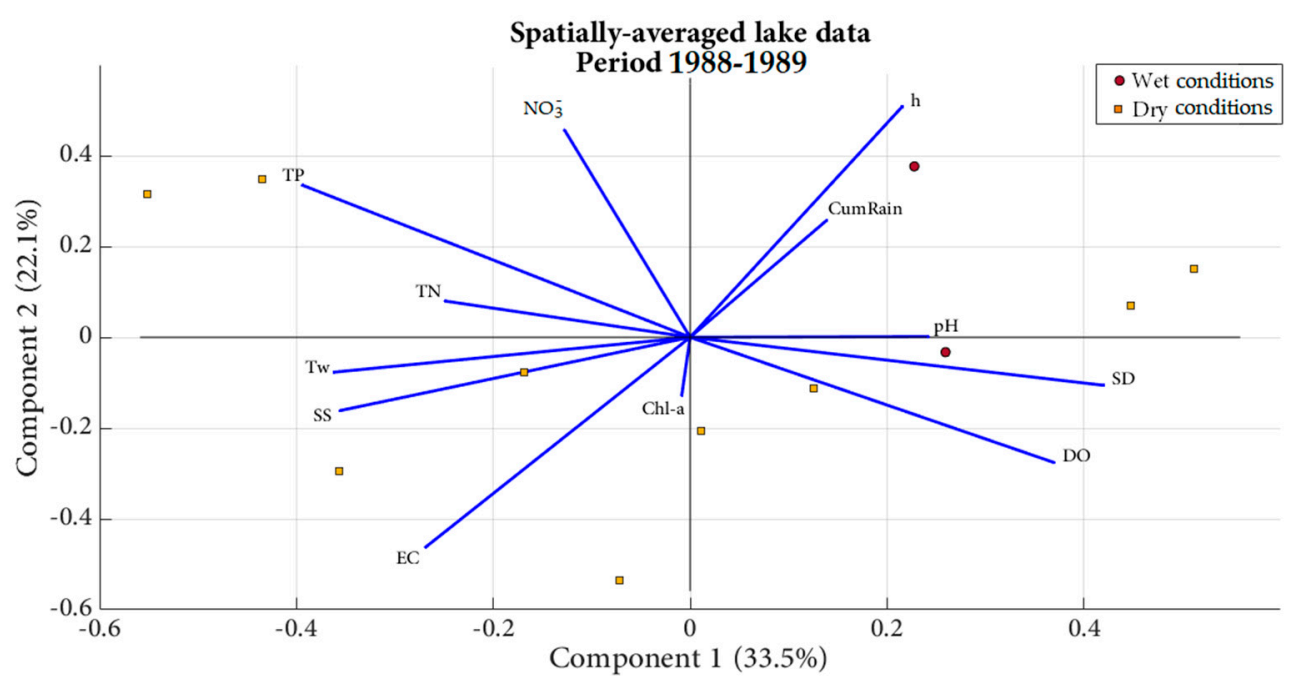

(a)

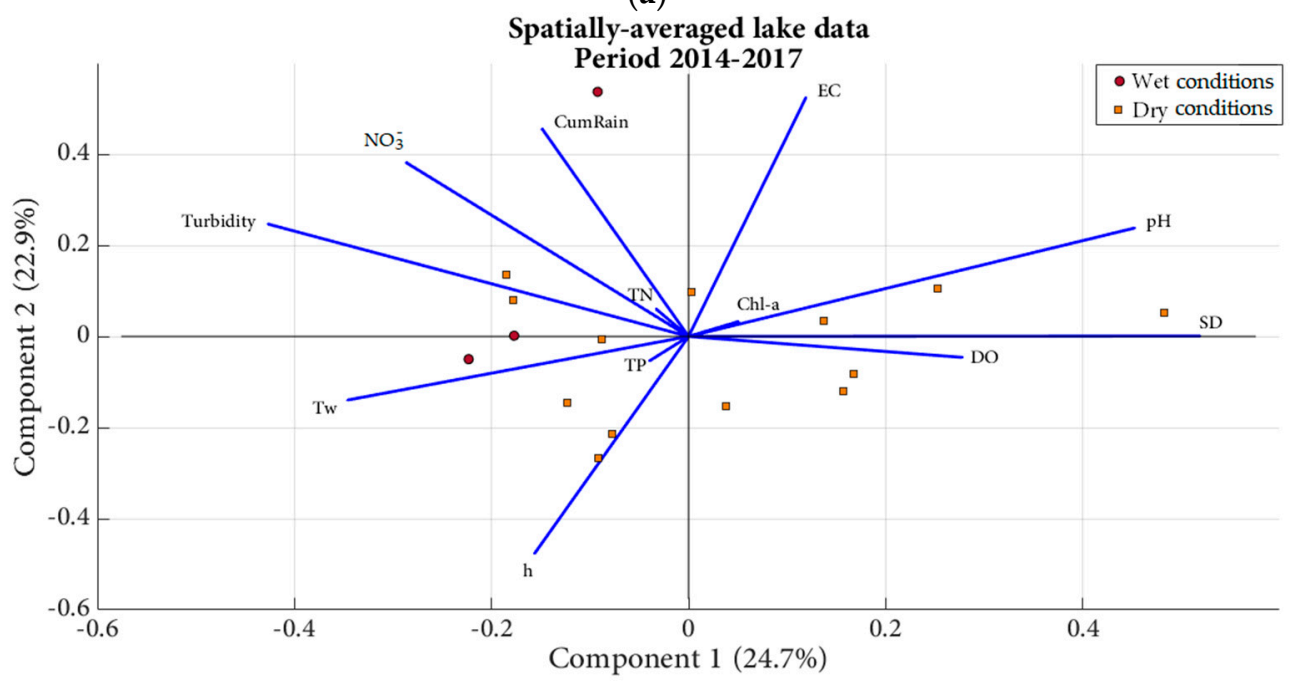

(b)

Figure 10. Principal component analyses (PCAs) biplots of spatially-averaged lake data for: (a) 1988-1989 (Composite dataset DS1: JICA/ANNP/DMH-DINAC); and (b) 2014-2017 (Composite dataset DS2: CEMIT-UNA II/ANNP/CIH-Itaipú/DMH-DINAC).

\subsubsection{Time Series Reconstruction of Trophic State Indices and Nutrient Limitation Assessment}

Reconstructed time series of modified trophic state indices (MTSI) based on SD, Chl-a and TP (Figure 11a-c), and of the trophic state index (TSI) based on TN (Figure 11d), characterise Ypacaraí Lake as eutrophic for the 1988-1989 period. For the 2014-2017 period, values of MTSI (SD) and MTSI (TP) fell within the hypereutrophic range for extended periods, as opposed to MTSI (Chl-a), whose values in this period fell within the mesotrophic range, and TSI (TN), whose values in this period remained in the eutrophic range, except for exceptional, brief periods of apparent mesotrophic or even oligotrophic conditions (in April 2014 and April 2015). 


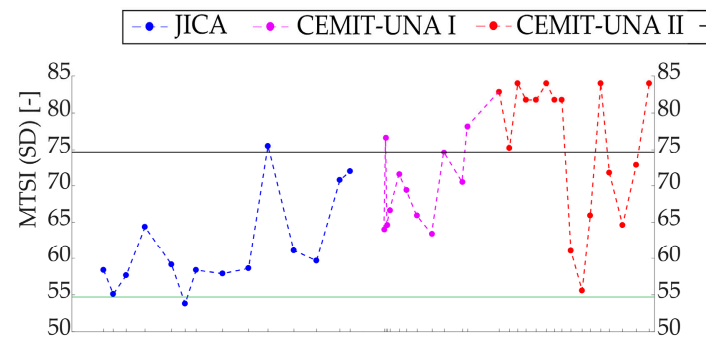

(a)

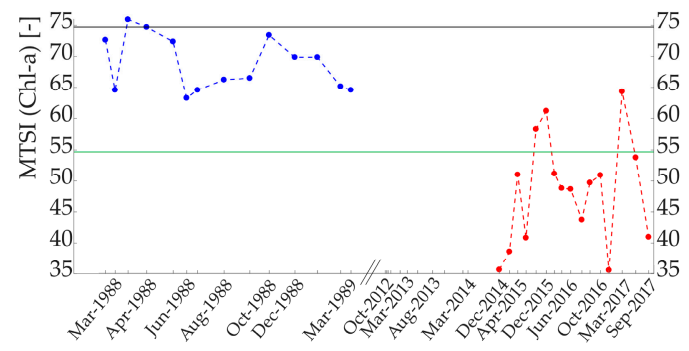

(b)

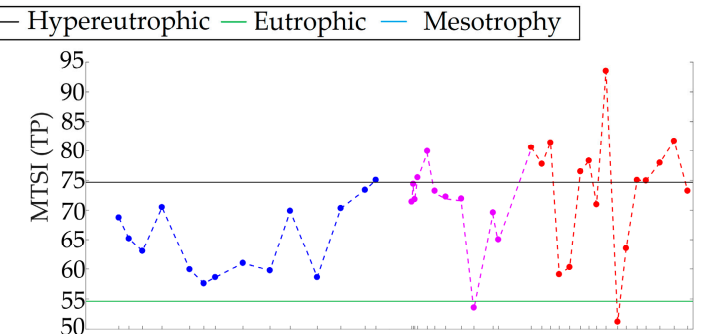

(c)

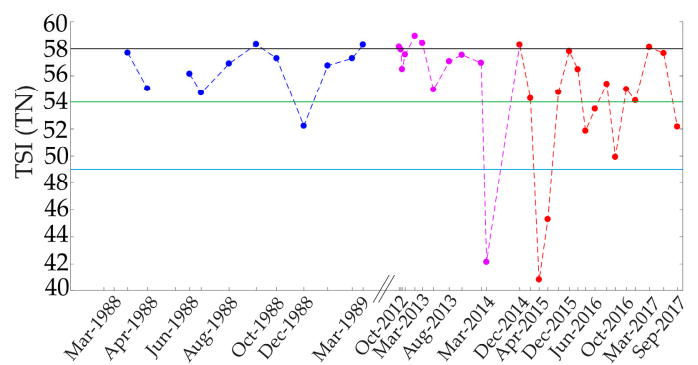

(d)

Figure 11. Time series of trophic state indices (TSI) based on (a) Secchi depth (SD); (b) chlorophyll-a (Chl-a); (c) total phosphorus concentration (TP); and (d) total nitrogen concentration (TN).

A significant downward trend ( $\tau=-0.414 ; S=-291 ; 95 \%$ confidence level) was found in the difference between TSI (TN) and TSI (TP), which presented negative values throughout both considered periods (1988-1989 and 2012-2017) (Figure 12a). This is indicative of increasingly limiting nitrogen concentrations in the lake, also evidenced by the significant downward trend $(\tau=-0.394 ; S=-277$; $95 \%$ confidence level) in the TN to TP ratio. With few exceptions, starting from 2014, this ratio fell below the mass-based Redfield ratio, $\mathrm{N}: \mathrm{P}=7.2: 1$, corresponding to the classical atomic Redfield ratio of $\mathrm{N}: \mathrm{P}=16: 1$ (Figure 12b).

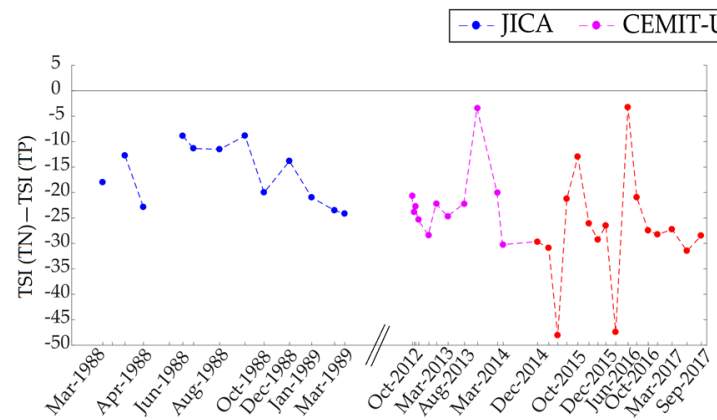

(a)

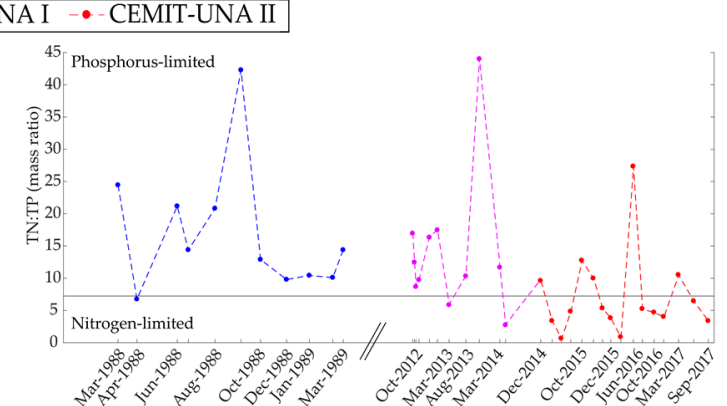

(b)

Figure 12. Time series of (a) the difference, TSI (TN)-TSI (TP); and (b) the ratio, TN:TP, with respect to the mass-based Redfield ratio (black horizontal line at TN:TP $=7.2$, corresponding to an atomic Redfield ratio of $\mathrm{N}: \mathrm{P}=16: 1$ ), both indicative of the type of nutrient limitation in the lake.

\section{Discussion}

\subsection{Factors Affecting Primary Production}

As can be expected from the basin-scale changes in land use that have occurred over the last decades (increasing runoff from urban expansion, greater erosion from deforestation, and loss of erosion-controlling and pollution-mitigating wetland areas), the mean concentrations of total suspended solids have almost doubled in recent years (2014-2017) with respect to the late 1980s (from 
23.2 to $40.2 \mathrm{mg} \cdot \mathrm{L}^{-1}$ ). This is also reflected by a negative trend in water transparency, evidenced by a significantly lower mean Secchi depth of $0.222 \mathrm{~m}$ in 2014-2017 as opposed to $0.513 \mathrm{~m}$ in 1988-1989.

Primary production in Ypacaraí Lake, hypothesised in the past to be limited by phosphorus due to the presence of P-binding $\mathrm{Fe}^{3+}$, both in the water column and in the interstitial water in the sediments, would thus be presently light limited. This could explain the lower mean chlorophyll-a concentration of recent years $\left(8.79 \mu \mathrm{g} \cdot \mathrm{L}^{-1}\right.$ in $2014-2017$, as opposed to $54.3 \mu \mathrm{g} \cdot \mathrm{L}^{-1}$ in 1988-1989), despite the fact that phosphorus concentration in the lake appears to have remained at high values, within a range that is characteristic of eutrophic and hypereutrophic lakes, at least since 1988. This is also evident from the reconstructed time series of MTSI (TP) (Figure 11c).

According to these results, should light penetration increase enough to allow for significant phytoplankton growth, the limitation would then be given by nitrogen, whose mean concentration has decreased over time from $1910 \mu \mathrm{g} \cdot \mathrm{L}^{-1}$ in $1988-1989$ to $1340 \mu \mathrm{g} \cdot \mathrm{L}^{-1}$ in $2014-2017$, rather than by phosphorus, whose mean concentration has more than doubled in this period, from 124 to $256 \mu \mathrm{g} \cdot \mathrm{L}^{-1}$.

This could potentially be configuring an unnatural secondary nitrogen limitation arising from the phosphorus enrichment of the lake, an effect that has already been reported for other shallow subtropical lakes (e.g., Lake Okeechobee [94]). Even though, in this case, we were not able to demonstrate, by means of the difference, TSI (TN)-TSI (TP), that Ypacaraí Lake is not naturally nitrogen limited, a trend towards increasing nitrogen limitation was identified (Figure 12a). Moreover, values of the TN to TP ratio have presented a significant negative trend over the last 30 years and, in 2012-2017, consistently fell below the mass-based Redfield ratio (Figure 12b), supporting the hypothesis of a rather recent transition from phosphorus to nitrogen limitation.

These conditions might explain the shift of the system towards Cylindrospermopsis raciborskii dominance (at the beginning of the warmer period) observed in the lake starting from 2012. In fact, these cyanobacteria can bloom not only in low-light conditions, but are also able to fixate atmospheric nitrogen, a trait that allows them to grow in nitrogen-limited waters [97], as opposed to the non-diazotrophic Microcystis aeurigonosa, which was markedly more dominant in previous years and is now managing to bloom only after Cylindrospermopsis raciborskii populations collapse [65]. Although this hypothesis might seem to contrast with the fact that nitrogen fixation is energy intensive [98], light energy in this lake quite limited due to elevated turbidity; this is supported by the fact that $\mathrm{N}$-fixating heterocysts were indeed found in C. raciborskii specimens sampled between 2012 and 2014 [65]. The reason why C. raciborskii prevails over other diazotrophic cyanobacteria that are also present in the lake, such as Anabaena sp., remains to us, however, an open question.

\subsection{Complex Hydro-Morphological and Hydro-Ecological Conditions}

PCAs performed on the two selected datasets, DS1 (1988-1989) and DS2 (2014-2017), pointed out the high degree of complexity in the functioning of Ypacaraí Lake. When taken together, the first two principal components, PC1 and PC2, accounted for $55.6 \%$ and $47.6 \%$ of the total variances of DS1 and DS2, respectively. This strongly suggests it is not possible to significantly reduce the number of variables that one needs to consider if one wants to fully capture the dynamic behaviour of this lake (i.e., without losing significant information).

On one hand, PC1 seems to have distinguished among data with high values of SD, $\mathrm{pH}$ and $\mathrm{DO}$, and low values of water turbidity (in this case largely attributable to SS), Tw (which nevertheless remained above $15^{\circ} \mathrm{C}$ ) and nutrient concentrations (which nevertheless remained consistently high, in the eutrophic and hypereutrophic ranges), and vice versa. A significant increase in photosynthetic activity during periods with high water transparency might explain the positive correlation between $\mathrm{PC} 1$ and $\mathrm{SD}$, and $\mathrm{pH}$ and $\mathrm{DO}$, as photosynthesis consumes free carbon dioxide $\left(\mathrm{CO}_{2}\right)$, elevating the $\mathrm{pH}$ by pushing chemical equilibrium towards lower concentrations of hydrogen ions $\left(\mathrm{H}^{+}\right)$, and produces molecular oxygen $\left(\mathrm{O}_{2}\right)$, elevating DO. Once again, this supports the hypothesis that pelagic primary production in this lake is currently limited by light rather than by nutrients. Should this be the case, however, Chl-a concentrations would expectedly be highly correlated with PC1 too, which does not 
appear to be the case. This might be explained by the relatively lower water temperatures observed during periods of high transparency in these datasets, but longer time series of these variables are required to confirm this, as no periods of high transparency during spring and summer months were available at the time of this study.

On the other hand, PC2 seems to have distinguished between high values of electrical conductivity (EC) and low lake levels, the concentration of EC-contributing ions being higher during dry periods when evaporation becomes a significant component of the water balance. In this sense, a good positive linear correlation $\left(r=0.85 ; r^{2}=0.72\right)$ was found between EC and estimated evaporation volumes, a result that suggests it should be possible to accurately estimate one as a function of the other and vice versa. This result could turn out to be relevant, as it has been proposed that, in shallow lakes, EC might be used as an indicator of pollution [99] given its positive correlation with the concentrations of dissolved ions, such as nitrates, ammonium and ortho-phosphates, all of which are, in general, more difficult to measure.

It is notable that, with respect to lake level, the contribution of cumulative rain to PC2 seems to have shifted from 1988-1989 to 2014-2017, indicating that the water level in this lake is not only determined by the amount of precipitation in the basin. This has already been observed in previous studies, in which the flow carrying capacity of the Salado River, the outflow of the lake, was found to be fundamental for the regulation of the lake's water level. To fully assess this effect, however, hydraulic modelling studies are required, for which a bathymetric survey of the Salado River, presently not available, is warranted. These studies would also allow for a better understanding of how this river interacts with the Paraguay River, especially during major floods, and how recent interventions, such as the construction of the Luque-San Bernardino highway, which not only altered the morphology of the Salado River, but also reduced the extension of wetland areas north of the lake, have affected the overall functioning of the system.

\subsection{Challenges for Restoration}

It is unclear whether Ypacaraí Lake ever presented clear water conditions, so attempting to restore them might not be ecologically sound. Supposing the affirmative case, of the many strategies we could think of to push the lake back to the clear water state, food web manipulation would probably have, in the long term, very limited success, as this lake supports a very rich fish diversity that would likely quickly adapt.

Reducing current phosphorus loading (estimated to be of 45 tons per year [81]) is clearly advisable. Current P-loading per unit area can be roughly estimated to be $0.75 \mathrm{~g} \cdot \mathrm{m}^{-2} \cdot \mathrm{year}^{-1}$. This is well above critical P-loading estimates for turbidification found, through modelling studies, for many other shallow lakes [5]. It is also particularly close to the highest estimate of $0.78 \mathrm{~g} \cdot \mathrm{m}^{-2} \cdot \mathrm{year}^{-1}$ found for the also shallow and subtropical Lake Taihu [100]. Specific threshold estimates for Ypacaraí Lake are presently not available and would require similar modelling studies to be conducted. In any case, should it be that primary production in this lake was indeed once phosphorus limited, management efforts aiming to limit further phosphorus enrichment would be necessary to eventually restore natural phosphorus limitation (or nitrogen-phosphorus co-limitation).

Studies have shown, however, that even though reducing nutrient loading can lead to improvement of the ecological status of shallow subtropical lakes, the response may not be immediate due to internal loads being relatively more important in these systems than in their temperate counterparts [24]. This needs to be considered when estimating the expected recovery times of Ypacaraí Lake, as little is known about its internal P-load or the biochemical processes taking place in the sediments, which ultimately determine remineralisation rates.

\subsection{Challenges for Management}

Four main specific challenges for the management of Ypacaraí Lake can be identified: (a) the high administrative and political fragmentation of the basin; (b) the institutional setting, characterised 
by many actors whose responsibilities in relation to the management and monitoring of the lake and its system are, in many cases, either overlapping or not clearly assigned [55]; (c) the relevant legal framework at the national level, which is not always coherent, resulting in intrinsically difficult application [55], a challenge that is complemented by insufficient practical enforcement and control, which is typical of but not restricted to emerging economies; and (d) the segregation and lack of systematisation of data and information, and the need for regular pre-processing and quality control activities, without which, part of the collected data ends up being of limited use.

In relation to the latter, major improvements should be mentioned. In particular, the establishment, by the Itaipú Binational Entity, of a network of monitoring stations that are continuously generating data that are made available to the public, in real time, through an online platform administered by the $\mathrm{CIH}$, the importance of which has been clearly highlighted by their use in the present study. The knowledge base hereby developed represents too an important achievement for future, sustainability-oriented management of Ypacaraí Lake, as it unifies data, outputs and conclusions from a variety of previous studies and integrates them with novel information. In this respect, it is important to say that, although a unified knowledge base does not necessarily readily translate into action [101], the socioeconomic and cultural importance of this lake in Paraguay sets an ideal political scenario for future interventions and further research.

\subsection{Opportunities for Research}

In addition to all previously mentioned research gaps that are specific to this shallow, subtropical lake, two key aspects present opportunities to push the state of the art of shallow lakes theory and subtropical limnology forward, both of which we illustrate, in red, in Figure 13: (a) its complex hydro-morphological and hydro-ecological dynamics in the context of a rapidly urbanising, densely-populated, humid subtropical region of a developing country that is subjected to increasingly frequent extreme rainfall events and that cyclically suffers the effects of ENSO; and (b) the reported disappearance, following the intense cyanobacterial blooms of 2012-2013, of tube-dwelling invertebrate communities $[61,67]$.

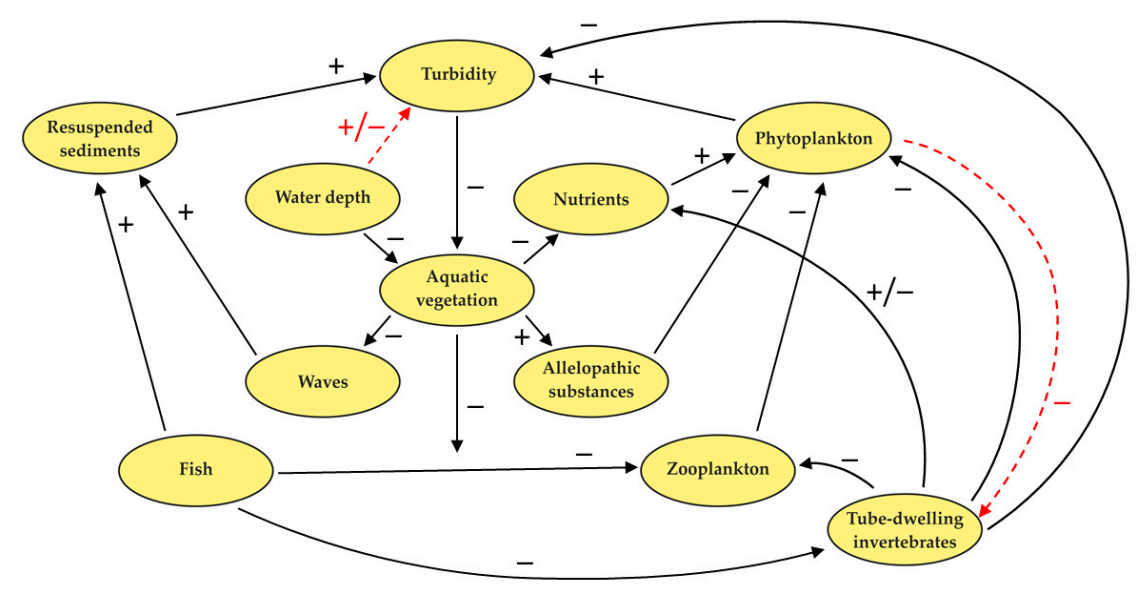

Figure 13. Opportunities offered by Ypacaraí Lake to push the state of the art of shallow lakes theory and subtropical limnology forward, given by the context-dependent positive/negative effect of water depth on turbidity and the negative feedback of phytoplankton (cyanobacteria) on tube-dwelling invertebrates. Modified from Scheffer et al. 1993 [2] and Hölker et al. 2015 [102].

With regard to the first aspect, we can say that, as reported for seven shallow, subtropical lakes in Florida [103], hydro-morphological factors play a fundamental role in determining ecological processes in Ypacaraí Lake. For instance, its increasingly higher water turbidity that would currently be limiting its primary productivity more than nutrients is largely related to increasing concentrations 
of suspended solids. Higher water levels during floods can therefore improve water transparency via the dilution of suspended solids in a larger volume of water, having the seemingly contradictory effect of favouring macrophytes over phytoplankton, the former being traditionally considered to be negatively affected by water depth. During droughts, lower water levels with highly concentrated suspended solids may actually worsen conditions for macrophytes. These effects, which have also been observed in shallow, subtropical Lake Apopka [104], are, however, not straightforward, as they are very much affected by the hydraulic response of the system (i.e., lake retention time) to hydro-meteorological factors, such as the intensity, duration and frequency of flood-producing extreme rainfall events, and the characteristics of the basin that determine its response in terms of erosion and run-off, which ultimately increase sediment input. As previously explained, the hydraulic regime, meteorological patterns and sediment dynamics are all changing in Ypacaraí Lake because of major engineering interventions, land use and climate change.

In relation to the second aspect, we can say there is now ample evidence that benthic tube-dwelling invertebrates, such as chironomids, can significantly alter multiple important ecosystem functions and thus play a central role in shallow lakes [102]. They compete with pelagic filter feeders for particulate organic matter, which can exert a high grazing pressure on phytoplankton, microorganisms, and perhaps small zooplankton, thus strengthening benthic-pelagic coupling. Furthermore, intermittent pumping by these invertebrates oxygenates the sediments, influencing microbe-mediated biogeochemical functions. Recent modelling studies provide strong evidence that they can even improve the resilience of a shallow lake that is in the clear water stable state, modifying the threshold for the shift between this and the turbid water stable state, their absence thus pushing the system further towards the latter [102].

The disappearance of these organisms from the sediments of Ypacaraí Lake, the cause of which remains unclear, might be explained by (a) oxygen shortages that, even though many invertebrates, including chironomids, are physiologically and behaviourally adapted to cope with, can lead to their elimination; or (b) cyanotoxins, toxic metabolites that cyanobacteria secrete and can cause acute and chronic effects, biochemical alterations and changes in the life cycle of aquatic invertebrates [105]. The first mechanism, on one hand, reportedly occurred in Kleiner Gollinsee, a shallow temperate lake in Germany that experienced a severe brownification-anoxia feedback event. This facilitated a persistent state of anoxia that occasionally extended to the water surface and resulted in the near-complete loss of macroinvertebrates [106]. The second mechanism, on the other hand, was observed in Lake Syczyńskie, a shallow temperate lake in Poland, where chironomid numbers in the sediments dwindled following high microcystin concentrations during hypertrophic periods [107].

\section{Conclusions}

Ypacaraí Lake has great ecological value, its system being characterised by a diverse matrix of aquatic habitats that includes numerous streams and vast marsh areas besides the lake itself which sustains a rich biodiversity, particularly of fish. It also constitutes a major source of drinking and irrigation water for neighbouring towns and cities, sustaining local economies largely based on agriculture, livestock farming, fishing, tourism and recreation. Its proximity to Asunción, the capital of Paraguay, and its cultural significance, make its environmental degradation a sensitive issue in the country that is regularly echoed by national media. This further heightens the awareness of the population about its ecological status, which quickly translates into political interest, especially during electoral periods, and continuously motivates scientific research aiming to shed light on its complex functioning in the hope of designing more effective management strategies. Over the years, many studies and projects have been conducted, both nationally and internationally, in collaboration with countries such as Japan, the United States, Italy and The Netherlands. In this article, we summarised the history of these initiatives and reviewed their many outputs.

Unfortunately, despite these efforts, eutrophication of the lake is ongoing, evidenced by an upward trend in total phosphorus that has resulted, in recent years, in intense cyanobacterial blooms of 
toxin-producing species, such as Cylindrospermopsis raciborskii and Microcystis aeruginosa. A downward trend in chlorophyll-a has, however, been observed, likely due to a significant downward trend in water transparency that is explained by increasing concentrations of suspended solids. This can be attributed to urbanisation, deforestation and the loss of wetland areas, which have altered the hydrological and sedimentological responses of the system to increasingly frequent extreme rainfall events and to ENSO-related periodic floods and droughts.

Phytoplankton, which was hypothesised in the past to be limited by phosphorus, would thus be presently limited by an unfavourable underwater light climate, and, moreover, it is now likely that, whenever nutrient limitation does occur, it is given by nitrogen rather than by phosphorus, a conclusion supported by significant trends towards increasing nitrogen limitation. A significant downward trend in lake level confirms the impact of recent, major hydrological and hydraulic alterations in the basin, a factor whose relevance is not minor, as PCAs results show the lake's overall conditions are highly correlated with water depth.

Finally, there are many unresolved questions regarding the very special hydro-morphological and hydro-ecological conditions of Ypacaraí Lake. Some of them are lake-specific, including the lake's critical nutrient thresholds, the role of its internal phosphorus load, the factors controlling nutrient release from the sediments, the complex interactions between the streams and associated wetland areas, and between the wetlands and the lake itself, to cite a few. Other aspects, however, might be of a more general interest, such as the recent disappearance, following intense cyanobacterial blooms, of the lake's benthic chironomids, key components of a shallow lake system that have recently been shown to improve the resilience of a lake presenting clear water conditions. To us, Ypacaraí Lake is thus no longer just an important element of Paraguayan culture, but also a scientific treasure in a context that is ideal for future research and that we believe can help push the state of the art of shallow lakes theory and subtropical lake science forward.

Supplementary Materials: The following are available online at http:/ /www.mdpi.com/2071-1050/10/7/2426/ s1. Communication S1: Cultural significance of Ypacaraí Lake and political implications of its eutrophication in Paraguay, Communication S2: Depuration efficiencies of surrounding wetland areas, Figure S1: Wind rose for 2014-2017 wind measurements at the San Bernardino Nautical Club (CNSB), Figure S2: Supplementary thematic maps of the Salado River Basin, Figure S3: Hydrogeological map of aquifers subjacent to the Salado River Basin, Figure S4: Lake sampling/measurement stations of the datasets used in this study, Figure S5: Linear regressions between lake level (h) and electrical conductivity (EC), and between cumulative evaporation (Ev) and EC, Table S1: Recent journalistic articles on Ypacaraí Lake, Table S2: Fish species of Ypacaraí Lake (2008-2012 sampling campaign), Table S3a-e: Phytoplankton of Ypacaraí Lake, Table S4: Zooplankton of Ypacaraí Lake, Table S5: Reviewed studies on Ypacaraí Lake and other water bodies of its hydrological system, Table S6a-c: Sampling/measurement dates and variables of the JICA, CEMIT-UNA I and CEMIT-UNA II datasets.

Author Contributions: G.A.L.M.M. and L.H. equally contributed to this work and should be considered co-first authors. G.A.L.M.M. coordinated the project and wrote the paper. L.H. managed datasets, performed the statistical and other analyses and prepared the figures. M.T., G.Z. and F.H. helped conceive this article and supervised work by G.A.L.M.M. Work by L.H. and A.S. was supervised by M.T., G.Z., R.M.D.S. and G.A.L.M.M. Existing literature was reviewed by G.A.L.M.M., L.H. and A.S. Contributions to the contents of this article were provided by: G.Z. on management aspects; F.H. on general ecological aspects; M.B., G.A.B., C.R.Á. and I.P. on planktonic and benthic macroinvertebrate communities; M.I. on fish communities; F.M. on vegetation formations; R.M.D.S. and A.W. on hydrological aspects; J.E. and C.E. on the depurative role of wetlands; S.C. and L.D.N. on anthropic impacts; J.F.F. on water quality and sediments; S.C., I.P., J.F.F. and J.F.F.-M. on general research and management history; and J.M.S. on lake bathymetry.

Funding: This work was partially carried out as part of the Science for Management of Rivers and their Tidal Systems Erasmus Mundus Joint Doctorate (SMART EMJD) programme, funded by the Education, Audiovisual and Culture Executive Agency (EACEA) of the European Commission. Research was conducted together with MSc students of the University of Trento (UniTN), through UniTN-funded mobility periods in Paraguay, during which they were hosted by the Centre for Appropriate Technology (CTA) of the Faculty of Sciences and Technology (FCYT) of the "Nuestra Señora de la Asunción" Catholic University (UCNSA). Datasets used in these studies were produced by several initiatives funded by different institutions such as the Directorate of Meteorology and Hydrology (DMH) of the National Directorate of Civil Aeronautics of Paraguay (DINAC); the National Navigation and Ports Administration of Paraguay (ANNP); the Ministry of Public Works and Communications of Paraguay (MOPC); the National University of Asunción (UNA); the Itaipú Binational Entity; the International Hydroinformatics Centre (CIH); the Japan International Cooperation Agency (JICA); and the Inter-American Development Bank (IADB). 
Acknowledgments: We acknowledge the support of our respective home institutions, as well as the support of: DAPSAN-MOPC Director Claudia Crosa and staff members Karina Caballero and Bethania Tellechea; FCYT-UCNSA Dean Luca Cernuzzi and staff members; CTA-FCYT-UCNSA Director Roberto Lima and researchers Julián Báez, Félix Carvallo, Alberto Ramírez and Larissa Felip; Margarita Pereira (FIUNA); Javier Báez and all staff members of CEMIT-UNA; Nicolás Rodríguez and other staff members of DMH-DINAC; ANNP Navigation and Hydrography Manager José Luis Ávila; Itaipú Binational Entity, through the Coordination Director Pedro Domaniczky, and Reservoir Division Director Hilario José Luis Hermosa, and staff members of the latter, especially Ana Carolina Gossen, Gabriela Sosa, Luz Paola Inchausti and Franklin Iván Molinas; Moisés Ayala, Juan Núñez and Analía Hartelsberger; CIH Coordinator Daniel Vázquez and staff members; David Fariña Gómez (SEAM); Harry Osvaldo Guth Acuña (ERSSAN), Derlis Esteche (Fundapueblos), Juan Carlos Bóbeda, Pedro Gaete, Elena Benítez and Barbara Ritterbusch-Nauwerck; and Marco Toffolon's lake research group at the University of Trento, especially Marina Amadori, Sebastiano Piccolroaz and MSc student Ruben Sadei. Finally, we thank the four anonymous reviewers for their valuable comments on our original manuscript, as well as Emma Crum and Geraldene Wharton for proofreading it and providing feedback on English grammar and style.

Conflicts of Interest: The authors declare no conflict of interest. The funding sponsors had no role in the design of the study; in the collection, analyses, or interpretation of data; in the writing of the manuscript, and in the decision to publish the results.

\section{Appendix A}

The recorded history of scientific research on Ypacaraí Lake dates back to 1937, the first known study being a physical and chemical characterisation of lake water by Francisco S. Facetti Villasanti, as reported in $[56,108]$. In his work, he remarked the presence of colloidal solids that affected water hardness, facilitating the formation of scums. A second study followed in 1945 [56] and a third one in 1965 [57].

Between 1976 and 1982, the National Service of Environmental Sanitation of Paraguay (SENASA) together with the Ministry of Public Health and Social Welfare of Paraguay (MSPBS), conducted an important study as part of a project on the classification of the country's surface waters, detecting the first signs of eutrophication of the lake. In the same period (1978), a report on its water quality was requested by SENASA Director Rogelio Aguadé to the Hydroconsult S.R.L. task force (C. López, F. J. Shade, J. F. Facetti-Masulli and R. López), which was followed by further reports in 1984, 1995 and 2005 (reported in [108]).

In 1988, Barbara Ritterbusch published a limnological study conducted at the Institute of Basic Sciences (ICB), now Faculty of Exact and Natural Sciences (FACEN) of the National University of Asunción (UNA) [70] by a team led by ICB Director Narciso González Romero, who had previously published some studies on the lake in 1967 [68] and 1986 [69]. For this study, several physical, chemical and biological parameters were monitored during the whole year of observation (1984), the analyses of which highlighted some crucial aspects of the lake's functioning. Specifically, the lake was found to be characterised by continuous external input, sedimentation and export of organic and inorganic matter, and poor primary and secondary production due to high water turbidity. Additionally, wastewater treatment, erosion control and effective regulation were identified as necessary for the improvement of water quality.

In response, the Paraguayan Government requested cooperation to the Government of Japan, which, through the Japan International Cooperation Agency (JICA), generated large amounts of data during a mission carried out between 1988 and 1989 [109]. An in-depth study on environmental aspects of Ypacaraí Lake and the Salado River Basin was produced, already mentioning the hydrological and hydraulic complexity of the system, given by the interaction between the Yukyry Stream, the Salado River, associated wetlands and the lake. The first bathymetric map of the lake was also drawn from sonar data and the mean level of the lake, $+1.20 \mathrm{~m}$ with respect to the CNSB reference zero, was calculated from the observation records (1965-1987) and used for calculating the lake's surface area and stored water volume.

The sediments were characterised for the first time in 1991 [52], finding low concentrations of toxic metals, the main metallic component being iron in its trivalent form $\left(\mathrm{Fe}^{3+}\right)$. No divalent iron 
$\left(\mathrm{Fe}^{2+}\right)$ was detected at the time. Primary productivity was hence hypothesised to be controlled by the phosphorus-binding properties of $\mathrm{Fe}^{3+}$.

Another important project financed by the United States Trade and Development Agency (USTDA) was conducted in 1995 by the consultancy firm Dames \& Moore, Inc. In the final report [110], it was underlined that the very comprehensive study carried out by JICA (1988-1989) had to "be modified to incorporate population increases and a deeper assessment of the alternatives pertaining to the collection, effluents treatment and protection of natural resources of the basins". The main conclusions and recommendations highlighted the need for both structural and non-structural measures, identifying some options for pollution control and lake management.

In 2000, the Paraguayan NGO Fundapueblos requested support to a survey team of the University of Padua (Italy), led by Giuseppe Bendoricchio, who recommended a series of actions to be taken for a proper management of Ypacaraí Lake and its system. Specifically, measures for the control of the lake level and the reduction of the amount of sediments transported towards the lake were described in the final report of the project [54].

In 2007-2008, a follow-up mission was carried out by the University of Padua (Italy) together with the Wise Use Agency of the Dutch Government, who came forward with proposals for a definitive solution of the lake's eutrophication problem [111]. In 2008, a pilot project on the use of bio-catalysts was also funded by The Netherlands, coordinated by the University of Wageningen, with the participation of the Ministry of Public Works and Communications of Paraguay (MOPC), the Secretariat of the Environment of Paraguay (SEAM) and the Multidisciplinary Centre for Technological Investigations of the National University of Asunción (CEMIT-UNA). As a result, the Paraguayan Government received a plan for the bio-remediation and management of Ypacaraí Lake.

Starting from one of the recommendations left by JICA, a second detailed bathymetric map was drawn by Jean Michel Sekatcheff in 2007. The on-site field work lasted for 35 consecutive days, and was carried out using a single manual probe, the results of which were simultaneously compared with sonar records. Since constant sediment resuspension and deposition are dynamically changing the lake bed, determining a continuous alteration of its bathymetry, the lake bottom was taken to be the one withstanding a force of $400 \mathrm{~N}$. The maximum depth recorded through this method was of $4.4 \mathrm{~m}$.

After the 2012 drastic cyanobacterial bloom, two main task force groups were created: one coordinated by the MSPBS together with SEAM, and an environmental commission directed by the President of the Supreme Court of Justice of Paraguay, a process that resulted, in 2014, in an agreement with the Itaipú Binational Entity to establish a network of monitoring stations, to create and maintain a limnological database, currently hosted by the International Hydroinformatics Centre (CIH), and to finance the periodical sampling campaigns of CEMIT-UNA, which had already started in 2012 with the scope of assessing the ecological conditions of the lake and the influence of environmental factors on cyanobacterial blooms. Other initiatives were also set in motion within this context, among which are a pilot project on water depuration by artificial floating macrophyte islands and the introduction of farmed fish of several native species into the lake.

In June-July 2014, the Reservoir Division of the Itaipú Binational Entity conducted a two-month bathymetric survey using an Acoustic Doppler Current Profiler (ADCP) SonTek RiverSurveyor M9. Data were post-processed in 2016, detecting a maximum depth of $3.7 \mathrm{~m}$, after which a third bathymetric map of the lake was drawn. In 2017, these bathymetric data were reprocessed to correct for water level variations that occurred during the period of the survey, detected by Andrea Salvadore and Luigi Hinegk. A fourth bathymetric map, which we present in this article (Figure 3), was thus produced.

Between 2015-2017, the Italian Consortium Beta Studio S.R.L.-Thetis S.p.A. conducted a project on the recovery of the lake for MOPC and the Inter-American Development Bank (IADB), funded by the European Union through the Spanish Agency for International Development Cooperation (AECID) [55,81]. The general aim of the project was to design a plan for the improvement of sanitary conditions in the basin. Support to this project was provided by INYMA Consult S.R.L., managed by Juan Escribá and Carmen Escribá, who contributed with on-site water quality measurements. 
Observations, upstream and downstream of the main water courses (Pirayú, Yukyry and Salado) were also carried out from February to June 2016, aiming to better understand wetland-mediated water discharges into the lake and assess the depuration efficiency of these areas (Communication S2 in the Supplementary Materials) [58].

Starting from 2017, the Department of Civil, Environmental and Mechanical Engineering of the University of Trento (UniTN, Italy), as part of Gregorio López Moreira's doctoral research project, established a collaboration with the "Nuestra Señora de la Asunción" Catholic University of Paraguay, to conduct joint research on Ypacaraí Lake through local supervision by Roger Monte Domecq S., of UniTN Master Students in Environmental Engineering, Andrea Salvadore [59] and Luigi Hinegk [53]. Later, UniTN Master Student in Environmental Engineering, Ruben Sadei, also initiated research on the resuspension of sediments and the release of nutrients from the lakebed into the water column, in collaboration with the Faculty of Engineering of the National University of Asunción (FIUNA), under the local supervision of Juan Francisco Facetti. These projects have resulted in a new interdisciplinary task force coordinated by Gregorio López Moreira, the first product of which is this article.

\section{References}

1. Lewontin, R.C. The meaning of stability. In Diversity and Stability in Ecological Systems. Brookhaven Symposium in Biology; U.S. Department of Commerce: Springfield, VA, USA, 1969; Volume 22, pp. 13-24.

2. Scheffer, M.; Hosper, S.H.; Meijer, M.L.; Moss, B.; Jeppesen, E. Alternative stable states in shallow lakes. Trends Ecol. Evolut. 1993, 8, 275-279. [CrossRef]

3. Scheffer, M. Alternative stable states in eutrophic, shallow freshwater systems: A minimal model. Hydrobiol. Bull. 1989, 23, 73-83. [CrossRef]

4. Scheffer, M. Multiplicity of stable states in freshwater systems. Hydrobiologia 1990, 200, 475-486. [CrossRef]

5. Janse, J.; De Senerpont Domis, L.N.; Scheffer, M.; Lijklema, L.; Van Lerie, L.; Klinge, M.; Mooij, W.M. Critical phosphorus loading of different types of shallow lakes and the consequences for management estimated with the ecosystem model PCLake. Limnologica 2008, 38, 203-219. [CrossRef]

6. Scheffer, M.; Van Nes, E.H. Shallow lakes theory revisited; various alternative regimes driven by climate, nutrients, depth and lake size. Hydrobiologia 2007, 584, 455-466. [CrossRef]

7. Van Nes, E.H.; Rip, W.J.; Scheffer, M. A Theory for Cyclic Shifts between Alternative States in Shallow Lakes. Ecosystems 2007, 10, 17-27. [CrossRef]

8. Hastings, A. Transients: The key to long-term ecological understanding? Trends Ecol. Evolut. 2004, 19, 39-45. [CrossRef] [PubMed]

9. Van Geest, G.J;; Roozen, F.; Coops, H.; Roijackers, R.M.M.; Buijse, A.D.; Peeters, E.; Scheffer, M. Vegetation abundance in lowland flood plan lakes determined by surface area, age and connectivity. Freshw. Biol. 2003, 48, 440-454. [CrossRef]

10. Søndergaard, M.; Jeppesen, E.; Jensen, J.P. Pond or lake: Does it make any difference? Arch. Hydrobiol. 2005, 162, 143-165. [CrossRef]

11. Janssen, A.B.G.; Teurlincx, S.; An, S.; Janse, J.H.; Paerl, H.W.; Mooij, W.M. Alternative stable states in large shallow lakes? J. Great Lakes Res. 2014, 40, 813-826. [CrossRef]

12. Van Nes, E.H.; Scheffer, M. Implications of spatial heterogeneity for catastrophic regime shifts in ecosystems. Ecology 2005, 86, 1797-1807. [CrossRef]

13. Van Nes, E.H.; Scheffer, M.; Van den Berg, M.S.; Coops, H. Dominance of charophytes in eutrophic shallow lakes-When should we expect it to be an alternative stable state? Aquat. Bot. 2002, 72, 275-296. [CrossRef]

14. Scheffer, M.; Rinaldi, S.; Gragnani, A.; Mur, L.R.; Van Nes, E.H. On the dominance of filamentous cyanobacteria in shallow, turbid lakes. Ecology 1997, 78, 272-282. [CrossRef]

15. Scheffer, M.; Szabó, S.; Gragnani, A.; Van Nes, E.H.; Rinaldi, S.; Kautsky, N.; Norberg, J.; Roijackers, R.M.M.; Franken, R.J.M. Floating plant dominance as a stable state. Proc. Natl. Acad. Sci. USA 2003, 100, 4040-4045. [CrossRef] [PubMed]

16. Meerhoff, M.; Mazzeo, N.; Moss, B.; Rodríguez-Gallego, L. The structuring role of free-floating versus submerged plants in a subtropical shallow lake. Aquat. Ecol. 2003, 37, 377-391. [CrossRef] 
17. Meerhoff, M.; Teixeira-de Mello, F.; Kruk, C.; Alonso, C.; González-Bergonzoni, I.; Pacheco, J.P.; Lacerot, G.; Arim, M.; Beklioğlu, M.; Brucet, S.; et al. Environmental Warming in Shallow Lakes: A Review of Potential Changes in Community Structure as Evidenced from Space-for-Time Substitution Approaches. In Advances in Ecological Research: Global Change in Multispecies Systems, Part I; Jacob, U., Woodward, G., Eds.; Elsevier Ltd.: New York, NY, USA, 2012; Volume 46, pp. 259-349. [CrossRef]

18. Kosten, S.; Jeppesen, E.; Huszar, V.L.M.; Mazzeo, N.; Van Nes, E.H.; Peeters, E.T.H.M.; Scheffer, M. Ambiguous climate impacts on competition between submerged macrophytes and phytoplankton in shallow lakes. Freshw. Biol. 2011, 56, 1540-1553. [CrossRef]

19. Scheffer, M.; Straile, D.; Van Nes, E.H.; Hosper, H. Climatic warming causes regime shifts in lake food webs. Limnol. Oceanogr. 2001, 46, 1780-1783. [CrossRef]

20. Meerhoff, M.; Clemente, J.M.; Teixeira de Mello, F.; Iglesias, C.; Pedersen, A.R.; Jeppesen, E. Can warm climate-related structure of littoral predator assemblies weaken the clear water state in shallow lakes? Glob. Chang. Biol. 2007, 13, 1888-1897. [CrossRef]

21. Singh, M.S.; Kuang, Z.; Maloney, E.D.; Hannah, W.M.; Wolding, B.O. Increasing potential for intense tropical and subtropical thunderstorms under global warming. Proc. Natl. Acad. Sci. USA 2003, 114, 11657-11662. [CrossRef] [PubMed]

22. Najibi, N.; Devineni, N. Recent trends in the frequency and duration of global floods. Earth Sys. Dynam. 2018, 9, 757-783. [CrossRef]

23. Perkins-Kirkpatrick, S.E.; Gibson, P.B. Changes in regional heatwave characteristics as a function of increasing global temperature. Sci. Rep. 2017, 7, 1-12. [CrossRef] [PubMed]

24. Beklioğlu, M.; Meerhoff, M.; Søndergaard, M.; Jeppesen, E. Eutrophication and Restoration of Shallow Lakes from a Cold Temperate to a Warm Mediterranean and a (Sub)Tropical Climate. In Eutrophication: Causes, Consequences and Control; Ansari, A.A., Sarvajeet, S.G., Lanza, G.R., Rast, W., Eds.; Springer Science+Business Media: Berlin, Germany, 2011; pp. 91-108. [CrossRef]

25. Schelske, C.L.; Lowe, E.F.; Kenney, W.F.; Battoe, L.E.; Brenner, M.; Coveney, M.F. How anthropogenic darkening of Lake Apopka induced benthic light limitation and forced the shift from macrophyte to phytoplankton dominance. Limnol. Oceanogr. 2010, 55, 1201-1212. [CrossRef]

26. Waters, M.N.; Schelske, C.L.; Brenner, M. Cyanobacterial dynamics in shallow Lake Apopka (Florida, U.S.A.) before and after the shift from a macrophyte-dominated to a phytoplankton-dominated state. Freshw. Biol. 2015, 60, 1571-1580. [CrossRef]

27. Beaver, J.R.; Casamatta, D.A.; East, T.L.; Havens, K.E.; Rodusky, A.J.; James, R.T.; Taus, C.E.; Buccier, K.M. Extreme weather events influence the phytoplankton community structure in a large lowland subtropical lake (Lake Okeechobee, Florida, USA). Hydrobiologia 2013, 709, 213-226. [CrossRef]

28. Rodusky, A.J. The influence of large water level fluctuations and hurricanes on periphyton and associated nutrient storage in subtropical Lake Okeechobee, USA. Aquat. Ecol. 2010, 44, 797-815. [CrossRef]

29. Chen, Y.; Qin, B.; Teubner, K.; Dokulil, M.T. Long-term dynamics of phytoplankton assemblages: Microcystis-domination in Lake Taihu, a large shallow lake in China. J. Plankton Res. 2003, 25, 445-453. [CrossRef]

30. Qin, B.; Xu, P.; Wu, Q.; Luo, L.; Zhang, Y. Environmental issues of Lake Taihu, China. Hydrobiologia 2007, 581, 3-14. [CrossRef]

31. De Faria, D.M.; Cardoso, L.S.; da Motta Marques, D. Epiphyton dynamics during an induced succession in a large shallow lake: Wind disturbance and zooplankton grazing act as main structuring forces. Hydrobiologia 2017, 788, 267-280. [CrossRef]

32. Da Rosa, L.M.; De Souza Cardozo, L.; Crossetti, L.O.; Da Motta-Marques, D. Spatial and temporal variability of zooplankton-phytoplankton interactions in a large subtropical shallow lake dominated by non-toxic cyanobacteria. Mar. Freshw. Res. 2017, 68, 226-243. [CrossRef]

33. Scasso, F.; Mazzeo, N.; Gorga, J.; Kruk, C.; Lacerot, G.; Clemente, J.; Fabián, D.; Bonilla, S. Limnological changes in a sub-tropical shallow hypertrophic lake during its restoration: Two years of a whole-lake experiment. Aquat. Conserv. Mar. Freshw. Ecosyst. 2001, 11, 31-44. [CrossRef]

34. González-Madina, L.; Pacheco, J.P.; Yema, L.; De Tezanos, P.; Levrini, P.; Clemente, J.; Crisci, C.; Lagomarsino, J.J.; Méndez, G.; Fosalba, C.; et al. Drivers of cyanobacteria dominance, composition and nitrogen fixing behavior in a shallow lake with alternative regimes in time and space, Laguna del Sauce (Maldonado, Uruguay). Hydrobiologia 2018. [CrossRef] 
35. Mazzeo, N.; Gorga, J.; Crosa, D.; Ferrando, J.; Pintos, W. Spatial and temporal variation of physicochemical parameters in a shallow reservoir seasonally covered by Pistia stratiotes L. in Uruguay. J. Freshw. Ecol. 1995, 10, 141-149. [CrossRef]

36. Pacheco, J.P.; Iglesias, C.; Meerhoff, M.; Fosalba, C.; Goyenola, G.; Teixeira-de Mello, F.; García, S.; Gelós, M.; García-Rodríguez, F. Phytoplankton community structure in five subtropical shallow lakes with different trophic status (Uruguay): A morphology-based approach. Hydrobiologia 2010, 646, 187-197. [CrossRef]

37. Iglesias, C.; Meerhoff, M.; Johansson, L.S.; González-Bergonzoni, I.; Mazzeo, N.; Pacheco, J.P.; Teixeira-de Mello, F.; Goyenola, G.; Lauridsen, T.L.; Sondergaadr, M.; et al. Stable isotope analysis confirms substantial differences between subtropical and temperate shallow lake food webs. Hydrobiologia 2017, 784, 111-123. [CrossRef]

38. Peel, M.C.; Finlayson, B.L.; McMahon, T.A. Updated world map of the Köppen-Geiger climate classification. Hydrol. Earth Syst. Sci. 2007, 11, 1633-1644. [CrossRef]

39. Belda, M.; Holtanová, E.; Halenka, T.; Kalvová, J. Climate classification revisited: From Köppen to Trewartha. Clim. Res. 2014, 59, 1-13. [CrossRef]

40. Directorate of Meteorology and Hydrology, National Directorate of Civil Aeronautics of Paraguay (DMH-DINAC). Meteorological Records for the Silvio Pettirossi International Airport (AISP) and the San Bernardino Nautical Club (CNSB) Stations; Database; DMH-DINAC: Asunción, Paraguay, 1959-2017.

41. Grimm, A.M.; Barros, V.R.; Doyle, M.E. Climate variability in southern South America associated with El Niño and La Niña events. J. Clim. 2000, 13, 35-58. [CrossRef]

42. Hirata, F.E.; Grimm, A.M. The role of synoptic and intraseasonal anomalies in the life cycle of summer rainfall extremes over South America. Clim. Dyn. 2016, 46, 3041-3055. [CrossRef]

43. Hirata, F.E.; Grimm, A.M. The role of synoptic and intraseasonal anomalies on the life cycle of rainfall extremes over South America: Non-summer conditions. Clim. Dyn. 2017, 49, 313-326. [CrossRef]

44. Pasquini, A.I.; Depetris, P.J. ENSO-triggered exceptional flooding in the Paraná River: Where is the excess water coming from? J. Hydrol. 2010, 383, 186-193. [CrossRef]

45. Báez, J.; Monte Domecq, R. Analysis of drought episodes in Paraguay. Clim. Chang. 2014, 127, $15-25$.

46. Méndez, S. Estudio del Comportamiento del Viento en San Bernardino; Itaipú Binational Entity: Hernandarias, Paraguay, 2017.

47. ANNP-Paraguay. Ypacaraí Lake: Water Level Records; Dataset; ANNP: Asunción, Paraguay, 1965-2016.

48. Reservoir Division, Department of Reservoir and Protected Areas, Superintendence of Environmental Management, Directorate of Executive Coordination, Itaipú Binational Entity. Ypacaraí Lake: Water level Records, San Bernardino Nautical Club (CNSB) Station; Dataset; Itaipú Binational Entity: Hernandarias, Paraguay, 2016-2017.

49. Reservoir Division, Department of Reservoir and Protected Areas, Superintendence of Environmental Management, Directorate of Executive Coordination, Itaipú Binational Entity. Bathymetric survey of the Ypacaraí Lake; Dataset; Itaipú Binational Entity: Hernandarias, Paraguay, 2014; Processed in 2017.

50. Wetzel, R.G. Limnology. Lake and River Ecosystems, 3rd ed.; Academic Press (Elsevier): San Diego, CA, USA, 2001; p. 34, ISBN 978-0-12-744760-5.

51. Riccomini, C.; Velázquez, V.F.; de Barros Gomes, C. Cenozoic lithospheric faulting in the Asunción Rift, eastern Paraguay. J. South Am. Earth Sci. 2001, 14, 625-630. [CrossRef]

52. Velázquez, R.; Alviso, R.; Facetti, J. Sediments of the Ypacaraí Lake. J. Radioanal. Nucl. Chem. 1992, 161, 233-238. [CrossRef]

53. Hinegk, L. Water and Nutrient Balance of Lake Ypacaraí and Salado River Basin (Paraguay): Data Analysis and Modeling. Master's Thesis, University of Trento, Trento, Italy, 29 March 2018.

54. Bendoricchio, G. Detención e Reversión del Proceso de Deterioro de la Cuenca del lago Ypacaraí. Misión de Identificación Para la Gestion Ecológica de la Cuenca del Lago Ypacarai_- Paraguay; Technical Report; ARPA Veneto: Padua, Italy, 2000.

55. Beta Studio-Thetis S.p.A. Plan de Saneamiento Integral de la Cuenca del Lago Ypacaraí: Diagnóstico de la Situación Actual del Lago Ypacaraí y su Cuenca; Technical Report; Beta Studio S.R.L.: Padua, Italy; Thetis S.p.A.: Venice, Italy, 2015.

56. Facetti Villasanti, F.S. Análisis físicoquímicos de las aguas del Lago Ypacaraí. Química y Colegio Químico del Paraguay 1945, 8/9, 19. 
57. Facetti, J.F.; Facetti Villasanti, F.S. Trace Elements in Ypacaraí lake water. In Proceedings of the Fifth InterAmerican Symposium on Nuclear Energy, Valparaiso, Chile, 9-13 March 1964; Pan American Union: Washington, DC, USA, 1965; p. 105.

58. Escribá Ticoulat, J.; Escribá Sakoda, C. Informe de Evaluación de Nutrientes y Eficiencias de Depuración de los Humedales del Lago Ypacaraí; INYMA Consult S.R.L.: Asunción, Paraguay, 2016.

59. Salvadore, A. Hydro-Thermodynamical Modelling of the Shallow Lake Ypacaraí (Paraguay). Master's Thesis, University of Trento, Trento, Italy, 29 March 2018.

60. Peralta López, I.; Benítez Rodas, G.A.; Ávalos, C.; Araujo Florentín, C.M.; Escobar, A.; Astigarraga Escobar, O.; Nuñez Zarate, I.B.; Villalba Duré, G.; Acosta Brítez, R.R.; Alcaraz, R.; et al. Monitoreo de Calidad de Agua por Campañas de Muestreo en el Lago Ypacarai 2014; Technical Report; UNA: San Lorenzo, Paraguay, 2014.

61. Peralta López, I.; Benítez Rodas, G.A.; Ávalos, C.; Araujo Florentín, C.M.; Escobar, A.; Astigarraga Escobar, O.; Nuñez Zarate, I.B.; Villalba Duré, G.; Acosta Brítez, R.R.; Alcaraz, R.; et al. Monitoreo de Calidad de Agua por Campañas de Muestreo en el Lago Ypacaraí 2016; UNA: San Lorenzo, Paraguay, 2016.

62. López Arias, T.R.; Franco de Diana, D.; Fernández, V.; Benítez, C.; Sánchez, P.; López Vera, M.E.; Kurita, H.; Benítez, M.; Ramond, F.; Bobadill, N.; et al. Diangóstico Ecotoxicológico y Genotóxico de los Afluentes del Lago Ypacaraí Mediante bioensayos con Daphnia magna Straus, Danio rerio, Lactuca sativa L. y Allium cepa L. Investigaciones y Estudios_UNA; UNA: San Lorenzo, Paraguay, 2013.

63. National Environmental Sanitation Service of Paraguay (SENASA); Japan International Cooperation Agency (JICA). Plan de Mejoramiento de la Calidad de Agua del Lago Ypacaraí y su Cuenca; SENASA: Asunción, Paraguay, 2001.

64. Insaurralde, M.; Balbuena, E.; Frutos, A. Variedades de peces del lago Ypacaraí (Fish variety at Ypacaraí Lake). Compend. Cienc. Vet. 2013, 3, 13-21.

65. Benítez Rodas, G.A.; Villalba Duré, G.; Ávalos de Enciso, C.; Araújo Florentín, C.; Acosta Brítez, R.; Escobar, A.; Astigarraga Escobar, O.; Peralta López, I.; Cardozo Román, C. Influencia de factores fisicoquímicos sobre la biodiversidad de cianobacterias en el Lago Ypacaraí durante el periodo 2012-2014. Steviana 2017, 9, 15-25.

66. Benítez Rodas, G.; Dos Santos, M.; Núñez, A.; Villalba Duré, G.; Ávalos de Enciso, C.; Araújo Florentín, C.; Acosta Brítez, R.; Escobar, A.; Arenas, R.; Astigarraga Escobar, O.; et al. Primer reporte de floración por Ceratium furcoides (Levander) Langhans en el Lago Ypacaraí - Departamento Central, Paraguay. Steviana 2017, 9, 26-35.

67. Benítez, G.A.; Multidisciplinary Centre for Technological Investigations, National University of Asunción, San Lorenzo, Paraguay. Personal communication, 2018.

68. González Romero, N. Contribución al estudio del Fito y Zooplancton en el Paraguay. Rev. Soc. Cient. Parag. 1967, 5, 29-38.

69. González Romero, N. Estudio Limnológico del Lago Ypacaraí; Revista del Instituto de Ciencias Básicas; Universidad Nacional de Asunción: San Lorenzo, Paraguay, 1986; 188p.

70. Ritterbusch, B. Estudio limnológico del lago Ypacaraí. Revista de la Asociación de Ciencias Naturales del Litoral 1988, 19, 11-26. [CrossRef]

71. Darrigran, G.; Escurra de Drago, I. Invasion of the exotic freshwater mussel Limnoperna fortunei (Dunker, 1857) (Bivalvia: Mytilidae) in South America. Nautilus 2000, 114, 169-173.

72. Mereles, F. Contribución al estudio de la vegetación hidrófita de la cuenca del lago Ypacaraí. Rev. Soc. Cient. Parag. 1982, 17, 86-92.

73. Mereles, F. Estudio de las comunidades vegetales de la cuenca del lago Ypacaraí. Rev. Soc. Cient. Parag. 1985, 5, 35-48.

74. Mereles, F.; Basualdo, I.; Ortiz, M.; Soria, N. Contribución al estudio de la vegetación del valle del lago Ypacaraí II. Rev. Univ. Nac. Asunción 1991, 2, 56-59.

75. Mereles, F.; Degen, R.; López de Kochalca, N. Humedales del Paraguay: Breve reseña de su vegetación. Amazoniana 1992, 12, 305-316.

76. Mereles, F.; Department of Botany, Faculty of Chemistry, National University of Asunción, San Lorenzo, Paraguay. Personal communication, 2018.

77. Weiler, A.; Núñez, K.; Airaldi Wood, K.; Caballero-Gini, A.; Bauer, F.; Cardozo, R. Aves de la Reserva de Recursos manejados Lago Ypacarai. Rev. Soc. Cient. Parag. 2015, 19, 63-73. 
78. General Directorate of Statistics, Surveys and Censuses of Paraguay (DGEEC). Proyección de la Población por Sexo y Edad Según Distrito (2000-2025); Technical Report; DGEEC: Asunción, Paraguay, 2012.

79. Venohr, M.; Langhans, S.D.; Peters, O.; Hölker, F.; Arlinghaus, R.; Mitchel, L.; Wolter, C. The underestimated dynamics and impacts of water-based recreational activities on freshwater ecosystems. Environ. Rev. 2018, 26, 199-213. [CrossRef]

80. Ministry of Public Works and Communications of Paraguay (MOPC). Plan Estratégico Metropolitano de Asunción (PEMA); Technical Report; MOPC: Asunción, Paraguay, 2014.

81. Beta Studio-Thetis S.p.A. Plan de Saneamiento Integral de la Cuenca del Lago Ypacaraí: Modelación Matemática e Identificación de Acciones y Medidas de Mitigación; Technical Report; Beta Studio S.R.L.: Padua, Italy; Thetis S.p.A.: Venice, Italy, 2016.

82. Mann, H.B. Non-parametric tests against trend. Econometrica 1945, 13, 245-259. [CrossRef]

83. Sen, P.K. Estimates of the regression coefficient based on Kendall's tau. J. Am. Stat. Assoc. 1968, 63, 1379-1389. [CrossRef]

84. Kendall, M.G. Rank Correlation Measures; Charles Griffin: London, UK, 1975.

85. McMahon, T.A.; Peel, M.C.; Lowe, L.; Srikanthan, R.; McVicar, T.R. Estimating actual, potential, reference crop and pan evaporation using standard meteorological data: A pragmatic synthesis. Hydrol. Earth Syst. Sci. 2013, 17, 1331-1363. [CrossRef]

86. Murakami, M.; Oonisishi, Y.; Kunishi, H. A numerical simulation of the distribution of water temperature and salinity in the Seto Inland Sea. J. Oceanogr. Soc. Jpn. 1985, 41, 221-224. [CrossRef]

87. Carlson, R.E. A trophic state index for lakes. Limnol. Oceanogr. 1977, 22, 361-369. [CrossRef]

88. Toledo, A.P.D.; Talarico, M.; Chinez, S.J.; Agudo, E.G. A aplicação de modelos simplificados para avaliação do processo da eutrofização em lagos e reservatórios tropicais. In Proceedings of the 12th Congresso Brasileiro de Engenharia Sanitária e Ambiental, Camboriú, Brasil, 20-25 November 1983; pp. 1-34.

89. Toledo, A.P., Jr. Informe Preliminar Sobre os Estudos Para a Obtenção de um Índice Para a Avaliação do Estado Trófico de Reservatórios de Regiões Quentes Tropicais; Technical Report; CETESB: São Paulo, Brazil, 1990.

90. Salas, H.J.; Martino, P. A simplified phosphorus trophic state model for warm-water tropical lakes. Water Res. 1991, 25, 341-350. [CrossRef]

91. Lamparelli, M.C. Graus de trofia em corpos d'água do Estado de São Paulo: Avaliação dos métodos de monitoramento. Ph.D. Thesis, University of São Paulo, São Paulo, Brazil, 2004.

92. Cunha, D.G.F.; Do Carmo Calijuri, M.; Lamparelli, M.C. A trophic state index for tropical/subtropical reservoirs (TSItsr). Ecol. Eng. 2013, 60, 126-134. [CrossRef]

93. Kratzer, C.R.; Brezonik, P.L. A Carlson-type Trophic State Index for nitrogen in Florida lakes. J. Am. Water Resour. Assoc. 1981, 17, 713-715. [CrossRef]

94. Havens, K.E. Secondary nitrogen limitation in a subtropical lake impacted by non-point source agricultural pollution. Environ. Pollut. 1995, 89, 241-246. [CrossRef]

95. Håkanson, L.; Bryhn, A.C.; Hytteborn, J.K. On the issue of limiting nutrient and prediction of cyanobacteria in aquatic systems. Sci. Total Environ. 2007, 379, 89-108. [CrossRef] [PubMed]

96. Redfield, A.C. The biological control of chemical factors in the environment. Am. Sci. 1958, 46, $205-221$. Available online: http:/ / www.jstor.org/stable/27827150 (accessed on 2 July 2018).

97. Willis, A.; Chuang, A.W.; Burford, M.A. Nitrogen fixation by the diazotroph Cylindrospermopsis raciborskii (Cyanophyceae). J. Phycol. 2016, 52, 854-862. [CrossRef] [PubMed]

98. Zevenboom, W.; De Groot, G.J.; Mur, L.R. Effects of light on nitrate-limited Oscillatoria agardhii in chemostat cultures. Arch. Microbiol. 1989, 125, 59-65. [CrossRef]

99. Das, R.; Samal, N.R.; Roy, P.K.; Mitra, D. Role of Electrical Conductivity as Indicator of Pollution in Shallow Lakes. Asian J. Water Environ. Pollut. 2016, 3, 143-146.

100. Janssen, A.B.G.; De Jager, V.C.L.; Janse, J.H.; Kong, X.; Liu, S.; Ye, Q.; Mooij, W.M. Spatial identification of critical nutrient loads of large shallow lakes: Implications for Lake Taihu (China). Water Res. 2007, 219, 276-287. [CrossRef] [PubMed]

101. Cash, D.W.; Clark, W.C.; Alcock, F.; Dickson, N.M.; Eckley, N.; Guston, D.H.; Jäger, J.; Mitchell, R.B. Knowledge systems for sustainable development. Proc. Natl. Acad. Sci. USA 2003, 100, 8086-8091. [CrossRef] [PubMed]

102. Hölker, F.; Vanni, M.J.; Kuiper, J.J.; Meile, C.; Grossart, H.-P.; Stief, P.; Adrian, R.; Lorke, A.; Dellwig, O.; Brand, A.; et al. Tube-dwelling invertebrates: Tiny ecosystem engineers have large effects in lake ecosystems. Ecol. Monogr. 2015, 85, 333-351. [CrossRef] 
103. Havens, K.E.; Ji, G.; Beaver, J.R.; Fulton, R.S., III; Teacher, C.E. Dynamics of cyanobacteria blooms are linked to the hydrology of shallow Florida lakes and provide insight into possible impacts of climate change. Hydrobiologia 2017, 1-17. [CrossRef]

104. Havens, K.E.; Ji, G. Multiyear oscillations in depth affect water quality in Lake Apopka. Inland Waters 2018, 8, 1-9. [CrossRef]

105. Ferrão-Filho, A.S.; Kozlowsky-Suzuki, B. Cyanotoxins: Bioaccumulation and effects on aquatic animals. Mar. Drugs 2011, 9, 2729-2772. [CrossRef] [PubMed]

106. Brothers, S.; Köhler, J.; Attermeyer, K.; Grossart, H.P.; Mehner, T.; Meyer, N.; Scharnweber, K.; Hilt, S. A feedback loop links brownification and anoxia in a temperate, shallow lake. Limnol. Oceanogr. 2014, 59, 1388-1398. [CrossRef]

107. Kaczorowska, A.; Kornijów, R. Palaeoecological evidence for changes over the past 200 years in chironomid communities of a shallow lake exposed to cyanobacterial toxins. Aquat. Ecol. 2012, 46, 465-473. [CrossRef]

108. Facetti, M.J.F.; Lozano, A.F.; Schade, F.; Flores, O.F.; Delgado, M.; Dávalos, A. Estudios Hídricos en el Lago Ypacaraí-I. Rev. Soc. Cient. Parag. 2005, 10, 85-97.

109. Japan International Cooperation Agency (JICA) for the Technical Secretariat of Planning of Paraguay (STP). The Study on Water Pollution Control Plan for the Lake Ypacarai and its Basin; Technical Reports; JICA: Tokyo, Japan, 1989.

110. Undersecretariat of Environment and Natural Resources of the Ministry of Agriculture and Livestock of Paraguay (MAG). Environmental Evaluation of the Lake Ypacarai and the Bay of Asuncion; Technical Report; Dames \& Moore, Inc.: Tampa, FL, USA, 1995.

111. Wise Use International BV. La Limpieza Bioquímica del Contaminado Lago Ypacaraí, Paraguay; Technical Report; Wise Use International BV: Woerden, The Netherlands, 2008.

(C) 2018 by the authors. Licensee MDPI, Basel, Switzerland. This article is an open access article distributed under the terms and conditions of the Creative Commons Attribution (CC BY) license (http:/ / creativecommons.org/licenses/by/4.0/). 